\title{
The helix-loop-helix protein Id-2 enhances cell proliferation and binds to the retinoblastoma protein
}

\author{
Antonio Iavarone, ${ }^{1,3}$ Pushkal Garg, ${ }^{1}$ Anna Lasorella, ${ }^{1}$ Jennie $\mathrm{Hsu}^{1}{ }^{1}$ and Mark A. Israel ${ }^{1,2}$ \\ Preuss Laboratory, Brain Tumor Research Center of the Departments of ${ }^{1}$ Neurological Surgery and ${ }^{2}$ Pediatrics, School \\ of Medicine, University of California, San Francisco, California 94143 USA
}

Cell growth and differentiation are usually antagonistic. Proteins of the basic helix-loop-helix (bHLH) family bind DNA and play important roles in the differentiation of specific cell types. Id proteins heterodimerize with bHLH transcription factors, blocking their activation of lineage-specific gene expression and thereby inhibiting cellular differentiation. To examine the effect of Id-2 on cell proliferation, we overexpressed Id-2 in the human osteosarcoma cell line U2OS. Id-2 expression in U2OS reduced the serum requirement for growth and stimulated cellular proliferation by shortening the doubling time and increasing the percentage of cells in $S$ phase. We demonstrated that Id-2 expression was able to reverse the inhibition of cellular proliferation and the block in cell cycle progression mediated by the product of the retinoblastoma tumor suppressor gene pRB. This effect was not associated with changes in the state of $\mathbf{p R b}$ phosphorylation in transfected cells. In vitro, unphosphorylated $\mathrm{pRb}$ from cell lysates specifically bound Id-2 but was not able to bind a mutated form of Id-2 lacking the HLH domain that also did not antagonize the growth arrest by $p R b$. In vitro-synthesized $p R b$ containing mutations within the E1A/large T-binding pocket did not bind Id-2. However, wild-type pRb was able to bind to a region of Id-2 corresponding to only the HLH domain. In vivo, a physical association between Id-2 and $\mathrm{pRb}$ was seen in cross-linked extracts from SAOS-2 cells transfected with Id-2 and pRb. Our data identify a role for Id-2 in the regulation of cellular proliferation and suggest that the interaction between Id-2 and $\mathbf{p R b}$ is a molecular pathway over which synchronous changes in growth and differentiation are mediated in vivo.

[Key Words: Cell proliferation; differentiation; pRb; Id-2; helix-loop-helix]

Received December 16, 1993; revised version accepted April 27, 1994.

In virtually all eukaryotic tissues cell differentiation is associated with decreased proliferation (Alema and Tato 1987; Li and Olson 1992). During normal development, the acquisition of differentiated cellular characteristics is associated with a loss in proliferative potential (Baserga 1985). In addition, the most aggressive and fastest growing neoplasms are characterized by anaplasia, the loss of differentiated features (Robbins 1989). However, the molecular mechanisms responsible for linking together the maintenance of the undifferentiated state and high proliferative capacity are unknown.

Id proteins belong to a class of nuclear proteins known as helix-loop-helix (HLH) proteins (Benezra et al. 1990). The distinguishing feature of this class is an amino acid sequence motif predicted to form a HLH structure through which proteins dimerize (Murre et al. 1989a,b). Members of the HLH family acting as transcription factors typically contain a domain of basic amino acids 5 ' to the HLH motif (Tapscott et al. 1988). The basic domain of such transcription factors mediates their binding to DNA when these proteins dimerize (Davis et al. 1990;

${ }^{3}$ Corresponding author.
Voronova and Baltimore 1990). Id proteins lack the basic amino acid domain necessary for DNA binding. Consequently, Id proteins inhibit binding to DNA and transcriptional activation by heterodimerization with other bHLH proteins (Benezra et al. 1990; Sun et al. 1991). This mechanism is considered responsible for the inhibition of cell differentiation attributed to Id proteins in several systems (Jen et al. 1992; Kreider et al. 1992; Wilson et al. 1991). In agreement with this model, Id expression decreases in a variety of cell lines when they are induced to differentiate (Benezra et al. 1990; Biggs et al. 1992; Kawaguchi et al. 1992; Murray et al. 1992). Conversely, cell differentiation is inhibited by overexpressing Id (Jen et al. 1992; Kreider et al. 1992; Murray et al. 1992).

Three members of the $I d$ family have been identified in the mouse and in humans: Id-1 (Benezra et al. 1990; W. Zhu and M. Israel, pers. comm.), Id-2 (Sun et al. 1991; Biggs et al. 1992), and Id-3 [identified as HLH462.3 (Christy et al. 1991) in the mouse and as heir-1 (Ellmeier et al. 1992) or 1R21 (Deed et al. 1993) in humans]. All three members have a high degree of conservation in the HLH domain, and the proteins encoded by these genes have been shown to complex with other bHLH proteins, 
preventing them from binding to DNA and from activating tissue-specific transcription. There is also indirect evidence that $I d$ genes can contribute to cellular growth regulation (Christy et al. 1991; Deed et al. 1993). Id genes are highly expressed during early development while proliferation is occurring and are typically not expressed in most mature tissues (Biggs et al. 1992; Ellmeier et al. 1992). In addition, the expression of some members of the Id family can be rapidly induced by growth factor treatment of responsive cells (Christy et al. 1991; Deed et al. 1993). Enhancement of Id expression has been reported in osteoblastic cells after growth stimulation with bone morphogenetic protein-2 (Ogata et al. 1993). Furthermore, the muscle determination factor, MyoD, whose function is known to be inhibited by Id, is able to arrest cell growth in a number of cell lines (Crescenzi et al. 1990; Sorrentino et al. 1990). Although members of the HLH family, particularly the Id proteins, have been extensively implicated in protein-protein interactions responsible for the control of cell type-specific transcription, the demonstration of functional associations of these same HLH proteins with key regulators of cell cycle and cell proliferation has been limited.

The retinoblastoma gene $(R B)$ is a tumor suppressor gene and the protein encoded by this gene (pRb) functions as a negative growth regulator (Lee et al. 1987a; Huang et al. 1988). Three DNA tumor virus-transforming proteins, including SV40 T antigen, adenovirus E1A, and human papillomavirus $\mathrm{E} 7$, bind to $\mathrm{pRb}$ and reverse its growth suppressive function (De Caprio et al. 1988; Whyte et al. 1988, Munger et al. 1989|. Only the unphosphorylated form of $\mathrm{pRb}$ binds to these viral oncoproteins (Weinberg 1991). This form of $\mathrm{pRb}$ acts physiologically to maintain the cells in the $G_{0} / G_{1}$ phase of the cell cycle (Buchkovich et al. 1989; Goodrich et al. 1991). The cellular proteins with which $\mathrm{pRb}$ interacts include the product of the proto-oncogenes c-myc (Rustgi et al. 1991) and c-abl (Welch and Wang 1993), the transcription factor E2F (Chellappan et al. 1991; Helin et al. 1992; Kaelin et al. 1992), D-type cyclins (Ewen et al. 1993; Dowdy et al. 1993), and myogenic factors like MyoD and myogenin (Gu et al. 1993). The interaction between MyoD and pRb mediates not only the induction of myogenic differentiation but also cell cycle arrest, which is induced by this bHLH factor (Gu et al. 1993).

In this report we examine the hypothesis that the Id-2 protein plays a role in regulating cellular proliferation, in addition to its well-characterized effect in maintaining the undifferentiated state. We demonstrated an enhancement of cellular proliferation by overexpressing the protein Id-2 in a human cell line. Id-2 was also able to reverse the growth inhibition caused by $\mathrm{pRb}$, and a specific binding was demonstrated between Id- 2 and the active, unphosphorylated form of $\mathrm{pRb}$.

\section{Results}

Id-2 enhances cell proliferation in the human osteosarcoma cell line U2OS

When cells are forced to re-enter the cell cycle after re- lease from serum starvation, Id-2 mRNA peaks twice corresponding to the $G_{0} / G_{1}$ transition and late $G_{1}$ phase of the cell cycle (W. Zhu and M. Israel, pers. comm.). To study the role of Id-2 in cell proliferation and in cell cycle progression, human Id-2 cDNA was cloned in the vector pMEP4 (Invitrogen) in which a metallothionein promoter regulates Id-2 transcription. This recombinant molecule [pMEP4(Id-2)] was transfected into the osteosarcoma cell line U2OS (Lee et al. 1987b; Diller et al. 1990). This cell line is particularly well suited for the study of cellular proliferation because it encodes functional pRB and $\mathrm{p} 53$ and exhibits a serum dependency for proliferation (see below). Several independent clones of U2OS cells transfected with pMEP4(Id-2) or pMEP4 were isolated. Id-2 protein from nine of these clones and one pool of transfectants was immunoprecipitated with rabbit polyclonal antibodies raised against bacterial Id-2 protein (Fig. 1). All the clones transfected with pMEP4(Id-2) expressed higher amounts of Id-2 protein than the level of Id-2 found in the human neuroblastoma cell line SMS-KCNR, which exhibited the maximal endogenous level of Id-2 among numerous human cell lines that we examined (Fig. 1; data not shown). The 15-kD overexpressed Id-2 protein corresponded to the predicted molecular size of human Id-2 and comigrated with human Id-2 produced from the same cDNA in an in vitro transcription/translation system (data not shown). The band corresponding to the endogenous Id-2 protein from U2OS is barely visible after immunoprecipitation. U2OS cells overexpressing Id- 2 have been continuously maintained in culture for 1 year without any reduction in cell viability.

We determined the effect of constitutive Id-2 expression on the proliferation of U2OS osteosarcoma cells (Fig. 2A). Two independent clones [U2OS(Id-2) clones 2 and 13] and a pool of $\sim 100$ clones overexpressing Id-2 grew faster than individual clones [U2OS(pMEP4) clones 8 and 9] and a pooled population of cells transfected with vector alone (Fig. 2A, data not shown). The average population doubling time of the two clones transfected with pMEP4(Id-2) was $1.01 \pm 0.35$ days, considerably shorter than $2.49 \pm 0.51$ days for the two clones transfected with pMEP4. Similarly, the saturation density achieved by U2OS transfected with Id-2 [U2OS(Id-2)] was, on average, 2.5 times higher than that of U2OS(pMEP4) $\mid 35.4 \pm 9.3 \times 10^{4} \mathrm{cells} / \mathrm{cm}^{2}$ versus $14.1 \pm 1.3 \times 10^{4}$ cells/ $\mathrm{cm}^{2}$, respectively). To study the potential effects of Id-2 on the serum dependency of U2OS cells, the growth rate of U2OS(pMEP4) and U2OS(Id-2) was determined in different concentrations of fetal calf serum (FCS; Fig. 2B). At the FCS concentration of $0.1 \%$, U2OS(pMEP4) did not grow, whereas in these same conditions U2OS(Id-2) cells retained $20-30 \%$ of the proliferative capacity of cells growing in $10 \%$ FCS. The effect of Id- 2 overexpression on the distribution of cells in the cell cycle was determined by flow cytometric analysis of cells that had been labeled with bromodeoxyuridine (BrdU; Fig. 2C). Cell populations expressing Id-2 showed an increased number of cells in $S$ phase and a decreased number in $G_{1}$. These results demonstrate that Id-2 expression can enhance the growth potential of U2OS cells. 
Figure 1. Constitutive overexpression of Id-2 in the human osteosarcoma cell line U2OS. Cells $\left(10^{6}\right)$ from nine clones of U2OS transfected with Id-2 (ID-clones) and one pool of Id-2 transfectants (ID-pool) were metabolically labeled with $\left[{ }^{35}\right.$ S|methionine and $\left[{ }^{35} \mathrm{~S}\right]$ cysteine, lysed, and immunoprecipitated with rabbit polyclonal antibodies raised against bacterially synthesized human Id-2 (Anti-ID-2) or with preimmune serum (Pre). A similar immunoprecipitation was performed from a clone of U2OS transfected with pMEP4 DNA (Vector) and from the human neuroblastoma cell line SMS-KCNR (KCNR). Protein samples were electrophoresed in a $15 \%$ SDS-polyacrylamide gel. The migration of the Id-2 protein is indicated. (MW) ${ }^{14} \mathrm{C}-\mathrm{La}$ beled molecular mass markers (in $\mathrm{kD}$ ).

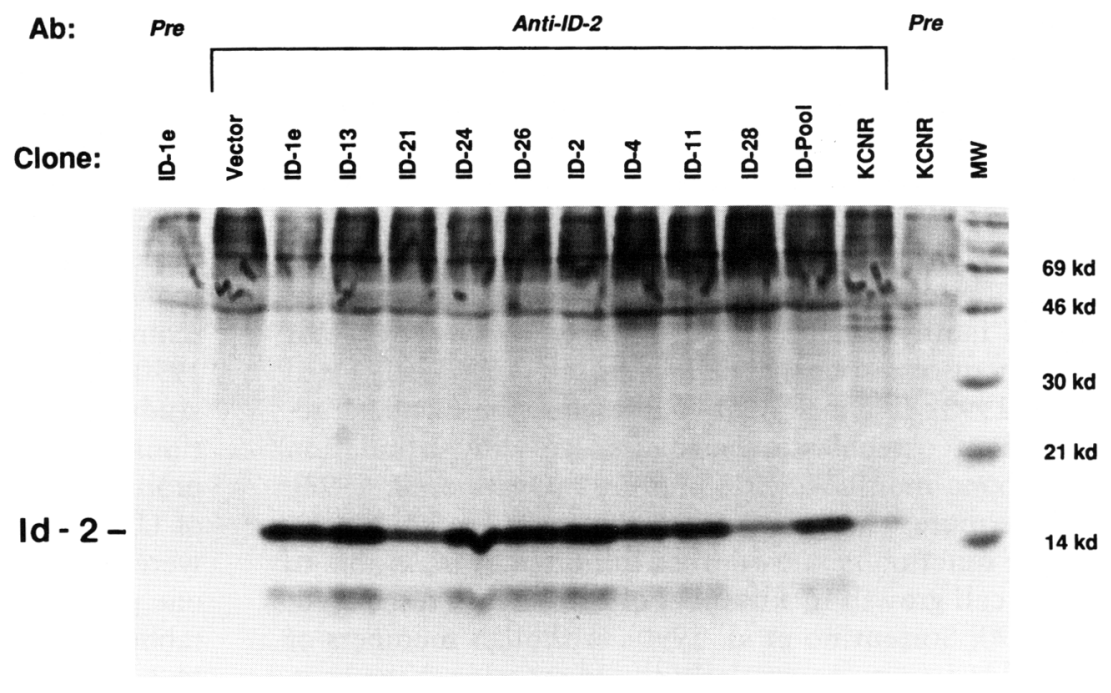

\section{Biological effects of Id-2 expression on $p R b$-mediated growth arrest}

A common feature of $\mathrm{p} 53$ and $\mathrm{pRb}$, two well-characterized tumor suppressor gene products, is their ability to inhibit cell proliferation (Huang et al. 1988; Baker et al. 1990). An assay used to demonstrate this effect measures the ability of tumor suppressor genes such as $R B$ to reduce the number of G418-resistant colonies when transfected in the presence of the neomycin-resistance gene (Qin et al. 1992; Zhu et al. 1993). The osteosarcoma cell line SAOS-2 lacks both functional $\mathrm{pRb}$ and $\mathrm{p} 53$, and the introduction of either pRb or p53 into these cells has been shown to reduce the proliferative potential of SAOS- 2 cells (Chen et al. 1990; Diller et al. 1990; Shew et al. 1990; Qin et al. 1992). We tested whether the effect of Id-2 on cell proliferation seen in U2OS was associated with a perturbation of the growth-suppressing effect of $\mathrm{pRb}$ or $\mathrm{p} 53$ in SAOS-2. High expression of Id- 2 in SAOS-2 cells was obtained when Id-2 cDNA was driven by a cytomegalovirus (CMV) promoter. In two experiments, the overexpression of $\mathrm{pRb}$ in SAOS-2 in the presence of an antisense construct of Id-2 (pCMVId-2AS) suppressed the colony-forming efficiency of these cells by $63 \%-73 \%$ (Table 1). However, the coexpression of sense Id-2 (pCMVId-2) relieved the growth suppression produced by $\mathrm{pRb}$ : In the presence of Id-2, pRb expression caused only a $15-30 \%$ reduction in colony-forming efficiency when compared with the clonogenic efficiency of SAOS-2 transfected without $R B$. Id-2 expression did not affect the growth inhibition produced by p53 in this assay /data not shown).

To analyze the pattern of expression of Id- 2 and $\mathrm{pRb}$ in transfected cells, SAOS- 2 cultures were examined $48 \mathrm{hr}$ after transfection by double-immunofluorescence staining using the anti-pRb monoclonal antibody pMG3-245 followed by a fluorescein-conjugated anti-mouse antibody and polyclonal anti-Id- 2 antibodies followed by a rhodamine-conjugated anti-rabbit antibody. Under the experimental conditions used in this immunoassay, en- dogenous $\mathrm{pRB}$ and Id-2 in SAOS-2 were undetectable (Fig. 3B,C). Cells transfected with expression vectors encoding either Id-2 or pRB showed strong nuclear staining for the exogenous proteins (Fig. 3A,D). Id-2 positive cells also had detectable cytoplasmic staining (Fig. 3A,E). In cultures cotransfected with Id-2 and pRb, staining of these two proteins was localized in the same cells (Fig. $3 \mathrm{E}, \mathrm{F} \mid$. However, a decreasing fraction of cells expressing $\mathrm{pRb}$ was observed during the 18 days following transfection and selection in G418 and cell lines ultimately established from such experiments expressed Id-2, but they did not express $\mathrm{pRb}$ (data not shown). This indicates that although Id-2 and pRb are expressed in the same cells, Id-2 by itself is not sufficient to overcome the selection for $\mathrm{pRb}$-negative variants that develop into stable transfectants of SAOS-2. These findings are concordant with experiments reported previously in which SAOS- 2 cells transfected with $R B$ give rise to permanent cell lines that do not express $\mathrm{pRb}$ (Qin et al. 1992). This has been observed regardless of the coexpression of $\mathrm{pRb}$-associated proteins, for example, cyclin D2, that are known to functionally antagonize the $\mathrm{pRb}$-mediated growth suppression (Ewen et al. 1993).

To examine whether the increase in colony-forming efficiency of $R B$-transfected cells in the presence of Id-2 is simply attributable to the ability of Id- 2 to enhance cell proliferation, SAOS- 2 cells transfected with pCMVId-2, pCMVId-2AS, or pCMV vector were isolated and expanded as stable cell lines. Clones and pools of SAOS-2 transfected with pCMVId-2 expressed Id-2 protein in amounts comparable with those found in U2OS cells transfected with pMEP4(Id-2), as determined by immunoprecipitation and immunofluorescence staining (data not shown). However, they did not show a faster growth rate when compared with cells transfected with pCMVId-2AS or pCMV vector (Fig. 4A). These data are consistent with similar colony-forming efficiencies found following transfection of SAOS-2 with either Id-2 or Id$2 A S$ in the absence of $\mathrm{pRb}$ (Table 1). Taken together, these findings indicate that the increase in colony-form- 

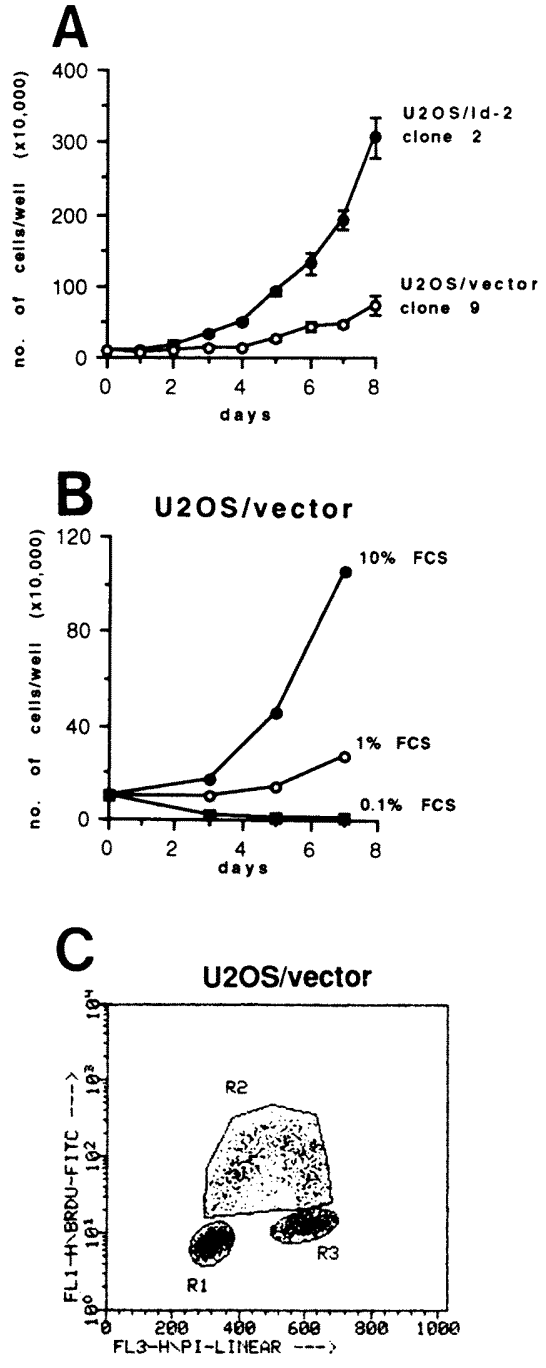

Cell Cycle Distribution (\%) following Id-2 Transfection In U2OS cells
Cell crcle phase

G1

$S$

G2/M

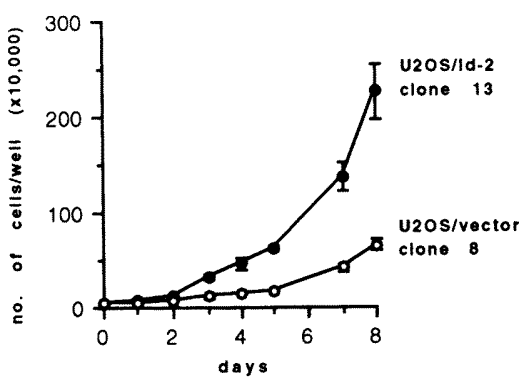

U2OS/Id-2

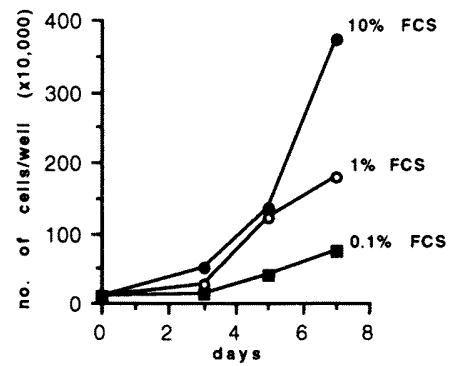

U2OS/ld-2

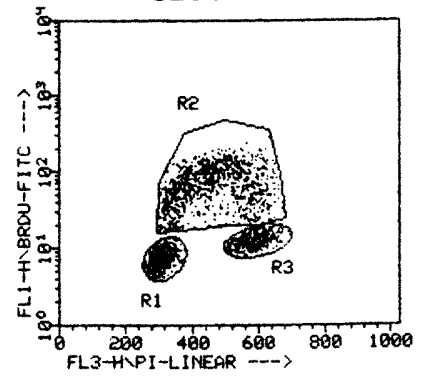

Figure 2. Effect of constitutive Id-2 expression on cell proliferation of U2OS. $(A)$ Cell growth kinetics of U2OS(pMEP4) and U2OS(Id-2) transfectants. (Left) $10^{5}$ or (right) $6 \times 10^{4}$ cells from individual clones of U2OS transfected with pMEP4 (open symbols) or pMEP4 (Id-2, solid symbols) were seeded into six-well plates on day 0 , and total viable cell numbers were determined at the indicated days (1-8). Each point represents the mean \pm the standard deviations of triplicate samples. $(B)$ Serum dependence for growth of U2OS(pMEP4) and U2OS(Id-2) transfectants. Duplicate cultures of cells transfected with pMEP4 (left) or cells transfected with pMEP4/Id-2, right) were cultured in medium containing the indicated concentrations of serum and counted on the indicated days. Note the different scales displayed on the $y$-axes to compare the effect of serum withdrawal on populations of cells with different growth rates. (C) Flow cytometric analysis. Control cells transfected with pMEP4 vector DNA (left) and cells transfected with Id-2 (right) were plated at $1 \times 10^{6}$ cells per 100 $\mathrm{mm}$ dish in media containing $10 \%$ serum. Two days later, cells were incubated in 10 $\mu \mathrm{M}$ BrdU for $2 \mathrm{hr}$, and stained with a fluorescein-conjugated monoclonal antibody to BrdU. FACS analysis for total DNA content and BrdU incorporation was performed on cells fixed in ethanol, treated with RNase, and stained with propidium iodide. Cells $\left(2 \times 10^{4}\right)$ were analyzed by FACScan with LYSYS II software. The windows show relative DNA content $(x$ axis) and fluorescence intensity (y-axis) of stained cells (dots). Cells with low DNA content and negative for fluorescent staining represent the $G_{0} / G_{1}$ population (R1). Cells with double amount of DNA content and negative for fluorescent staining represent the $G_{2} / M$ population (R3). Cells with an intermediate amount of DNA content and positive for fluorescent staining represent the S-phase population (R2). ing efficiency produced by Id- 2 in cells cotransfected with $R B$ is not the result of a nonspecific enhancement of cell proliferation by Id-2, which might obscure an independent growth inhibitory effect by $\mathrm{pRb}$. The expression of exogenous $\mathrm{pRb}$ in SAOS-2 results in the synthesis of $\mathrm{pRb}$ that is present exclusively in the active, unphosphorylated form (Qin et al. 1992). To determine whether Id-2 expression could reverse the growth-inhibitory effect of $\mathrm{pRb}$ by modifying its expression or its phosphorylation state, we examined the newly synthesized $\mathrm{pRb}$ in SAOS- 2 in the presence or in the absence of Id-2 expression (Fig. 4B). Western blot analysis of $\mathrm{pRb}$ in SAOS- 2 cells $48 \mathrm{hr}$ after transfection showed that Id-2 expression in these cells did not affect $\mathrm{pRb}$ expression or
$\mathrm{pRb}$ phosphorylation. $\mathrm{pRb}$ appears as a single band of similar intensity in the presence or in the absence of Id-2, comigrating with the unphosphorylated form observed in parental U2OS. These data demonstrate that Id- 2 does not inhibit $\mathrm{pRb}$ expression in SAOS- 2 cells and that the rescue of $\mathrm{pRb}$-mediated growth arrest is not dependent on a detectable phosphorylation of $\mathrm{pRb}$ in $I d-2$ transfected cells.

Expression of $\mathrm{pRb}$ in proliferating SAOS-2 blocks cell cycle progression and inhibits entry into $S$ phase (Goodrich et al. 1991). We evaluated pRB activity in the absence and in the presence of Id-2 coexpression in a transient transfection assay. SAOS- 2 cells were transfected with expression vectors encoding $\mathrm{pRb}$ and Id -2 , as well as 
Table 1. Reversal of $p R B$ growth suppression by Id-2

\begin{tabular}{|c|c|c|}
\hline \multirow[b]{2}{*}{ SAOS- 2 cells transfected with } & \multicolumn{2}{|c|}{ Average number of colonies } \\
\hline & experiment 1 & experiment 2 \\
\hline pßActvector + pCMVId-2AS & 442 & 174 \\
\hline $\mathrm{p} \beta A c t R B+p C M V I d-2 A S$ & $121(73 \%)^{a}$ & $65(63 \%)^{a}$ \\
\hline $\mathrm{p} \beta$ Actvector + pCMVId- 2 & 372 & 202 \\
\hline $\mathrm{p} \beta A c t R B+p C M V I d-2$ & $259(30 \%)^{\mathrm{a}}$ & $171(15 \%)^{\mathrm{a}}$ \\
\hline
\end{tabular}

SAOS-2 cells were transfected with the indicated expression constructs, split 1:8, incubated in the presence of G418 for 18 days, and stained. In these experiments, $R B$ expression was under the control of a $\beta$-actin promoter and $I d$ - 2 under the control of a CMV promoter. The percentage of inhibition by pRB was calculated according to the formula: $\%$ inhibition $=100-$ $\left[\left|n_{\mathrm{r}} / n_{\mathrm{c}}\right| \times 100\right]$, where $n_{\mathrm{r}}=$ number of colonies in $\mathrm{pRB}$ dishes and $n_{c}=$ number of colonies in dishes without $\mathrm{pRB}$.

${ }^{a}$ Calculation of percent reduction in colony-forming efficiency.

an expression plasmid for the cell surface marker CD20 to identify the transfected cells (Zhu et al. 1993). Following transfection, the cells were incubated in growth medium containing BrdU. The percentage of transfected cells progressing through $S$ phase was determined by a double immunofluorescence assay in which the fraction of CD20-positive cells that were also positive for BrdU staining was calculated. In two independent experiments, $\mathrm{pRb}$ expression reduced the percentage of cells in S phase from $40 \%$ to $16 \%$ and from $26 \%$ to $5 \%$ (Table 2 ). The coexpression of Id-2 increased the fraction of the transfected cells that were positive for BrdU staining up to $39 \%$ and $18 \%$, respectively. A mutant construct of Id-2 lacking the HLH domain [pCMVId-2( $\Delta \mathrm{HLH})]$ did not modify the block of progression through $S$ phase caused by $\mathrm{pRB}$ (Table 2). These results demonstrate that Id-2 can transiently antagonize the arrest of proliferation mediated by $\mathrm{pRb}$, and they are consistent with the data from the colony formation assay presented in Table 1 .

\section{Specific binding of human Id-2}

to the unphosphorylated form of $p R b$

Id proteins suppress differentiation by forming heterodimers with bHLH transcription factors (Benezra et al. 1990; Sun et al. 1991). To study the possibility that protein-protein interactions could be responsible for the effects of Id- 2 on cell proliferation and $\mathrm{pR} b$ growth inhibition described above, we prepared glutathione- $S$-transferase (GST) fusion proteins of human Id-2 (GST-Id-2) and of modified Id-2 lacking the entire HLH domain

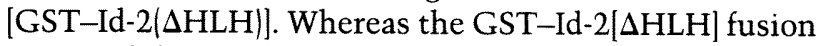
protein did not complex with the bHLH proteins E12 or MyoD, GST-Id-2 bound with comparable efficiency to both E12 and MyoD in vitro (data not shown). Therefore, the human Id-2 protein expressed as a GST fusion product was able to interact through its HLH domain with two bHLH proteins known to be physiologic partners of Id-1 and Id-2.

To test whether GST-Id-2 could form a specific com- plex with pRb, we incubated GST-Id-2 or GST-Id$2[\Delta \mathrm{HLH}]$ with lysates prepared from the human osteosarcoma cell lines U2OS and SAOS-2. Bound proteins were separated by SDS-PAGE, and the presence of $\mathrm{pRb}$ was detected by Western blot analysis. GST-Id-2 but not GST-Id-2[AHLH] bound a $110-\mathrm{kD}$ protein from the $\mathrm{U} 2 \mathrm{OS}$ lysate that was recognized by the anti-pRb antibody C-15 (Fig. 5). This protein comigrated with pRB immunoprecipitated with the anti-pRb monoclonal antibody C36 from the same cell lysate (Fig. 5) and was not bound by GST or GST-p53 (data not shown). In addition, both GST-Id-2 and GST-Id-2[DHLH] did not bind a 110$\mathrm{kD}$ protein when the experiment was done with lysates from SAOS-2 cells, which are known to lack a normal retinoblastoma protein (Fig. 5). Taken together, these data indicate that GST-Id-2 can form a specific complex with $\mathrm{pRb}$ in vitro and that the HLH domain contained in the Id-2 protein is required for this interaction.

We next asked whether the binding of $\mathrm{pRb}$ to GSTId-2 was specific for its unphosphorylated form. Lysates from the SAOS-2 and U2OS cell lines were prepared in anti Id-2
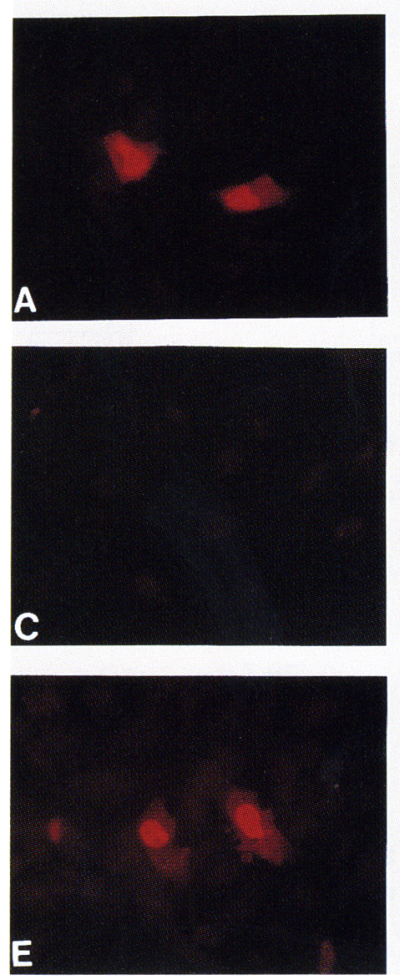

anti $\mathbf{p R B}$
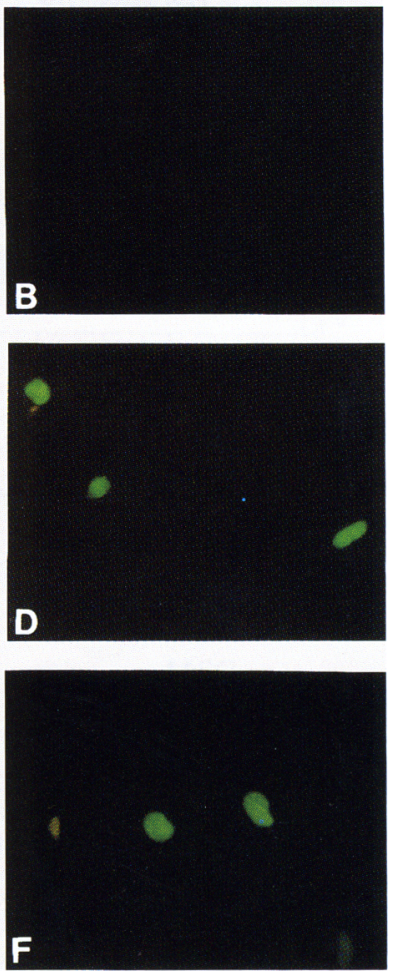

Figure 3. Expression of Id-2 and $\mathrm{pRb}$ in transfected SAOS-2 cells. Cells were processed for double immunofluorescence 48 $\mathrm{hr}$ after transfection with the following combinations of expression constructs: $(A, B)$, pCMVId- $2+$ p $\beta$ Actvector; $|C, D|$, pCMVvector $+\mathrm{p} \beta$ ActRB $; \quad(E, F), \quad$ pCMVId- $2+\mathrm{p} \beta A c t R B$. Fixed cells were indirectly immunostained for Id- 2 with rhodamine and for $\mathrm{pRB}$ with fluorescein. Photographs were taken from the same field using filters for rhodamine (left) and for fluorescein (right). 

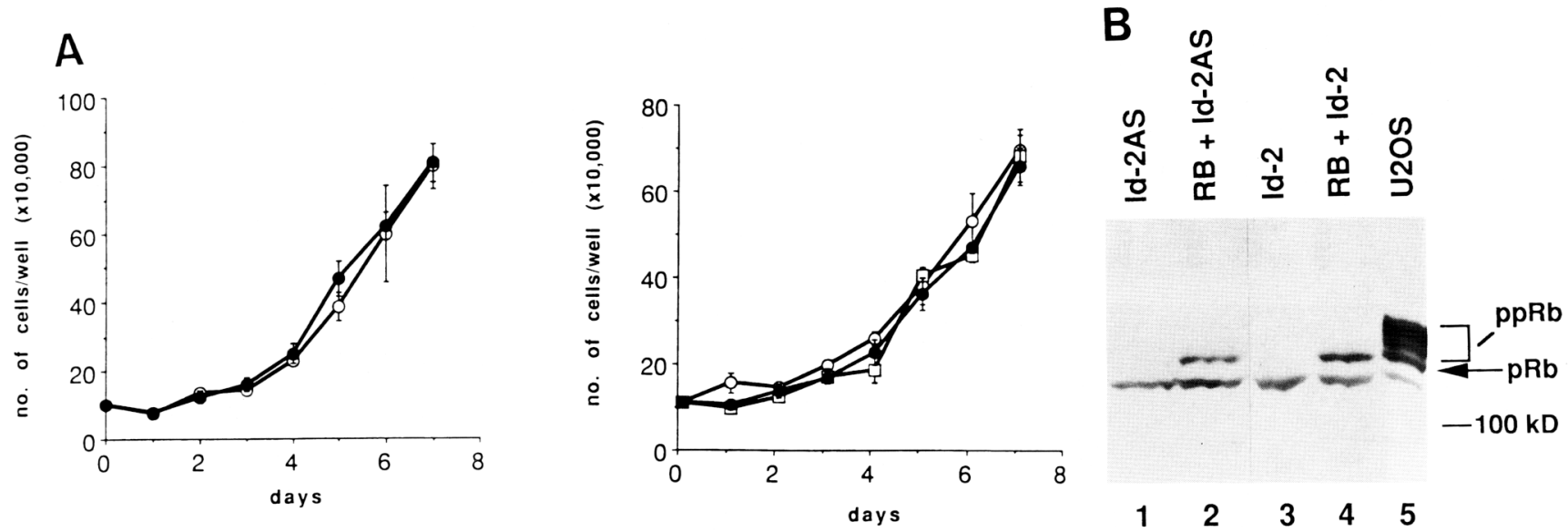

Figure 4. Analysis of Id-2 function in SAOS-2. (A) Cell growth kinetics of SAOS-2 transfectants. Cells $\left(10^{5}\right)$ from pools $\left.\mid l e f t\right)$ or individual clones (right) of SAOS-2 transfected with pCMVId-2 (O), pCMVId-2AS (O), or pCMVvector ( $\square$ ) were seeded into six-well plates on day 0 , and total viable cell numbers were determined at the indicated days (1-7). Each point represents the mean \pm the standard deviations of triplicate samples. $(B)$ Phosphorylation state of pRb in transfected SAOS-2 cells. Forty-eight hours after transfection with the same combinations of expression constructs shown in Table 1 (lane 1 , p $\beta$ Actvector + pCMVId-2AS; lane 2,

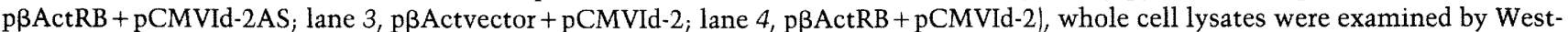
ern blot with the rabbit polyclonal anti-pRB antibody C-15. Immune complexes were detected with ECL (Amersham). Lane 5 contains lysates from $1 \times 10^{6}$ logarithmically growing U2OS osteosarcoma cells. The migration of the unphosphorylated (pRb) and hyperphosphorylated $(\mathrm{ppRb})$ forms of $\mathrm{pRb}$ in $6 \%$ SDS-polyacrylamide is indicated.

the presence or in the absence of phosphatase inhibitors and subsequently incubated with GST-Id-2. Lysates were also prepared from the cell line 293, which expresses the viral $\mathrm{pRb}$-binding protein E1A, and immunoprecipitated with a monoclonal antibody against E1A (M73) or against $\mathrm{pRb}(\mathrm{C} 36)$. A Western blot evaluating the presence of $\mathrm{pRb}$ demonstrated that only the fastest migrating form of $\mathrm{pRb}$ from U2OS, which has been shown previously to be unphosphorylated (Buchkovich et al. 1989), bound to GST-Id-2 (Fig. 6A). This form of $\mathrm{pRb}$ was bound with higher efficiency when phosphatase inhibitors were omitted from the preparation of the cell

Table 2. Reversal of pRB-mediated cell cycle arrest by Id-2

\begin{tabular}{|c|c|c|}
\hline \multirow{2}{*}{$\begin{array}{l}\text { SAOS- } 2 \text { cells } \\
\text { transfected with }\end{array}$} & \multicolumn{2}{|c|}{ Transfected cells in S phase $(\%)$} \\
\hline & experiment 1 & experiment 2 \\
\hline $\mathrm{p} \beta$ Actvector $+\mathrm{pCMVvector}$ & 40 & 26 \\
\hline $\mathrm{p} \beta A c t R B+$ pCMVvector & 16 & 5 \\
\hline pßActvector + pCMVId-2 & 41 & 28 \\
\hline p $\beta A c t R B+p C M V I d-2$ & 39 & 18 \\
\hline $\begin{array}{l}\text { p } \beta \text { Actvector + pCMVId-2- } \\
(\Delta \mathrm{HLH})\end{array}$ & & 30 \\
\hline $\begin{array}{l}\text { p } \beta A c t R B+p C M V I d-2- \\
(\Delta H L H)\end{array}$ & & 5 \\
\hline
\end{tabular}

SAOS-2 cells were transfected with the plasmids indicated plus an expression vector for the cell-surface marker CD20. After 48 $\mathrm{hr}$ they were incubated in medium containing BrdU for $2 \mathrm{hr}$. Double immunofluorescence was used to determine the percentage of CD20-positive cells that were stained with anti-BrdU antibody. The values represent the results from counting $\sim 300$ CD20-positive cells for each sample. lysates. The preparation of the lysates in the absence of phosphatase inhibitors resulted in greater amounts of unphosphorylated $\mathrm{pRb}$ being available for binding (data not shown). Furthermore, the $110-\mathrm{kD}$ protein bound to GST-Id-2 reacted with the mAb G99-549 used to probe the blot shown in Figure $6 \mathrm{~B}$ and comigrated with the unphosphorylated form of $\mathrm{pRb}$ interacting with $\mathrm{E} 1 \mathrm{~A}$ /Fig. 6B, lane 3). The antibody G99-549 specifically recognizes unphosphorylated $\mathrm{pRb}$ (PharMingen). Thus, GST-Id-2 can bind selectively in vitro to the unphosphorylated form of $\mathrm{pRB}$ that has been shown to function in the suppression of cell proliferation (Qin et al. 1992).

Id-2 does not interact with the bHLH region of E2F-1 and binds only $p R b$ with an intact pocket domain

The cellular transcription factor E2F-1 binds $\mathrm{pRb}$, and its DNA-binding region includes a domain predicted to form an HLH motif (Kaelin et al. 1992). To test whether the interaction between Id-2 and $\mathrm{pRb}$ could also involve binding of Id-2 with E2F-1, we transcribed and translated in vitro E2F-1 cDNA and the synthesized polypeptides, labeled with $\left.{ }^{35} S\right]$ methionine, were incubated with different GST fusion proteins (Fig. 7). As expected, the in vitro translation reaction gave rise to a doublet of 57 - and 60-kD polypeptides (Kaelin et al. 1992). These protein species bound very efficiently to a GST-Rb fusion protein that included the entire pocket domain /amino acids 379-928) of pRb. A point mutation in amino acid 706 of the $\mathrm{pRb}$ molecule (Cys $\rightarrow$ Phe) was sufficient to greatly reduce the binding affinity of GST-Rb to E2F-1. Neither GST-Id-2 or GST-MyoD showed any noteworthy bind- 


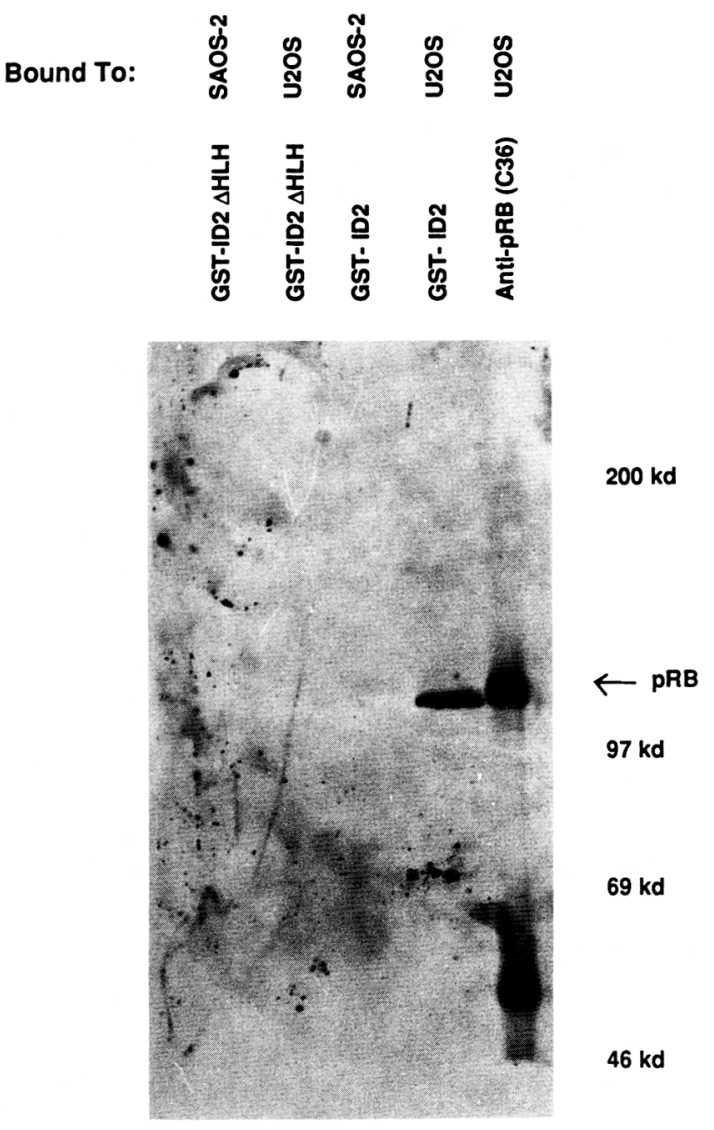

Figure 5. Binding of GST-Id-2 to $\mathrm{pRb}$ from the human osteosarcoma cell line U2OS. U2OS or SAOS- 2 cell extracts were incubated with GST-Id-2 or GST-Id-2 [ $\triangle \mathrm{HLH}]$. GST fusion-bound proteins, as well as proteins immunoprecipitated from U2OS by anti-pRb antibody $\mathrm{C} 36$, were separated by $8 \%$ SDS-PAGE, transferred to nitrocellulose, and probed with rabbit polyclonal $(\mathrm{C}-15)$ anti-pRb antibody. The migration of $\mathrm{pRb}$ is indicated.

ing to E2F-1 polypeptides. Thus, the specific binding of GST-Id-2 to unphosphorylated $\mathrm{pRb}$ does not involve a detectable interaction of GST-Id-2 with the pRb-binding factor E2F-1.

To study further the association between Id- 2 and $\mathrm{pRb}$, we prepared $\left[{ }^{35} S\right]$ methionine-labeled $\mathrm{pRb}$ in vitro by transcription and translation of a human $R B$ cDNA clone. The potential role of accessory factors participating in the binding of GST-Id-2 to pRb was tested by incubating in vitro-synthesized $\mathrm{pRb}$ with GST-Id-2 in the presence or in the absence of SAOS-2 lysate. GSTId-2 bound efficiently to in vitro-translated wild-type $\mathrm{pRb}$, regardless of the presence of the SAOS-2 extract (Fig. 8). The binding of GST-Id-2 to a mutated form of $\mathrm{pRb}$ [pRB $\Delta(303-404)]$ was greatly diminished, especially in the presence of the SAOS-2 extract. The RB cDNA encoded by $\mathrm{RB} \Delta(303-404)$ contains a deletion in region $\mathrm{A}$ of the pocket domain of $\mathrm{pRb}$ known to be essential for the association of $\mathrm{pRb}$ with adenovirus E1A or SV40 large $\mathrm{T}$ antigen (Hu et al. 1990). Furthermore, the translation products of $\mathrm{pRb}$ with molecular mass $>56 \mathrm{kD}$, which contain an intact pocket domain and bind E1A (Fig. 8, M73), show preferential binding to GST-Id-2 (Figs. 8 and 9). These data suggest that the binding of both E1A and Id-2 to $\mathrm{pRb}$ involves a similar region in $\mathrm{pRb}$, which must retain an intact pocket domain.

Specificity of the interaction of $p R b$ with proteins containing an HLH domain

A direct interaction has been described between $\mathrm{pRb}$ and the myogenic bHLH transcription factor MyoD. This

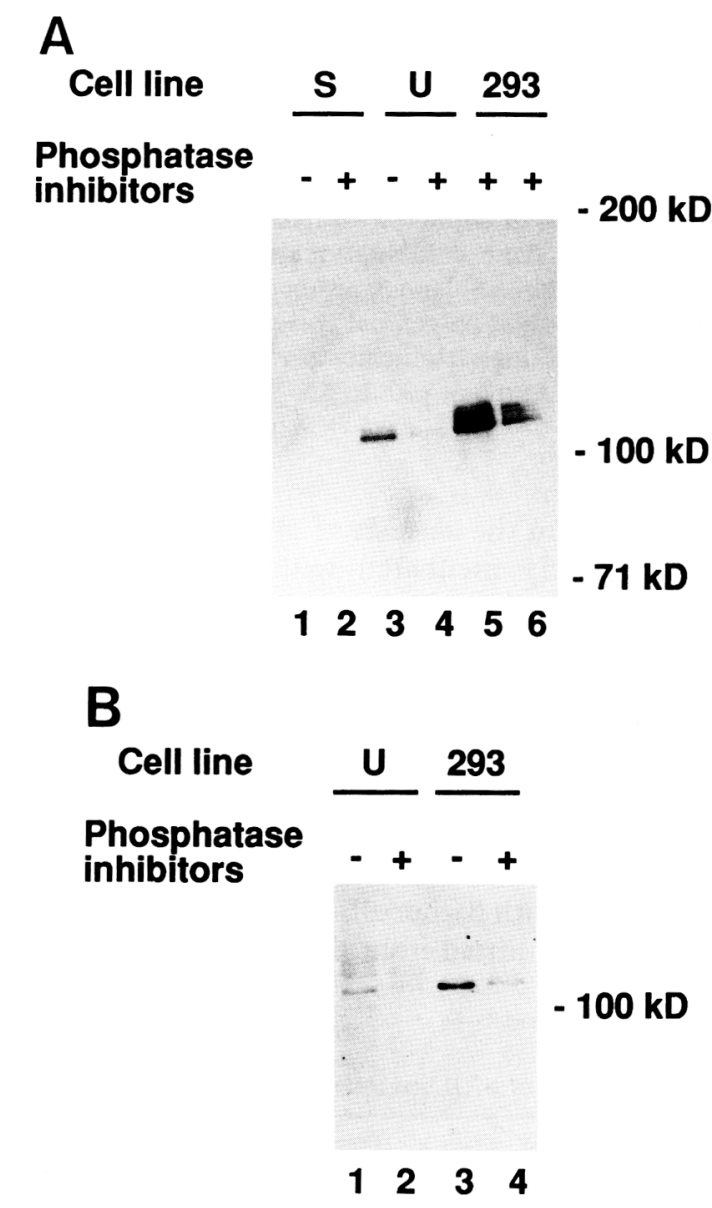

Figure 6. GST-Id-2 specifically binds unphosphorylated $\mathrm{pRb}$. (A) Lysates from SAOS-2 (lanes 1,2) and U2OS (lanes 3,4) were prepared in the absence (lanes 1,3 ) or in the presence (lanes 2,4) of phosphatase inhibitors and bound to GST-Id-2. Lysates from cell line 293 (lanes 5,6 ) were prepared in the presence of phosphatase inhibitors and immunoprecipitated with M73 (antiElA, lane 5) or C36 (anti-pRb, lane 6) antibodies. Proteins were separated by $8 \%$ SDS-PAGE, and after transfer, the blot was probed with the anti-pRb antibody C-15. (B) Lysates from U2OS (lanes 1,2) and 293 (lanes 3,4) were prepared in the absence (lanes 1,3 ) or in the presence (lanes 2,4) of phosphatase inhibitors. The lysates from U2OS were bound to GST-Id-2, and the lysates from 293 were precipitated with the antibody M73. Proteins were separated by $8 \%$ SDS-PAGE, and after transfer, the blot was probed with the antibody G99-549, which is specific for the unphosphorylated form of $\mathrm{pRb}$. 


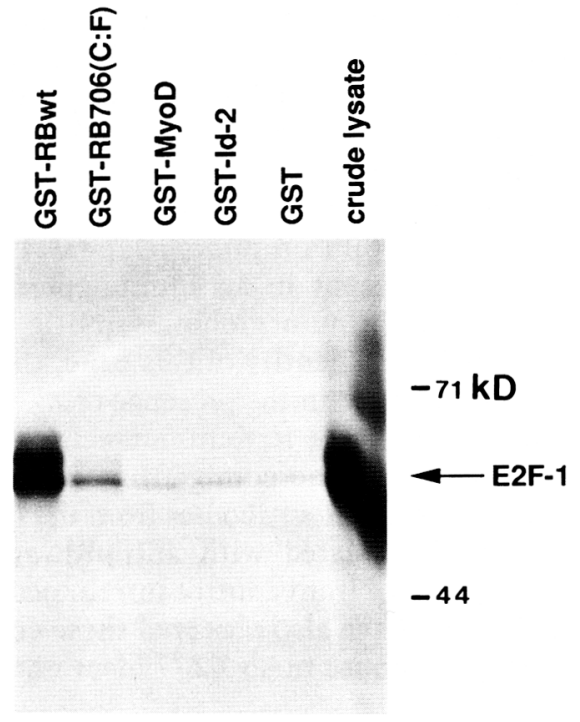

Figure 7. Lack of binding of in vitro-translated E2F-1 to fusion proteins containing the $\mathrm{HLH}$ domain. In vitro-translated ${ }^{35} \mathrm{~S}$ labeled E2F-1 was incubated with the following GST fusion proteins bound to glutathione-Sepharose: (1) Wild-type GST$\mathrm{Rb}$, including amino acids 379-928 of pRb (GST-RBwt); (2) $\mathrm{GST}-\mathrm{Rb}$ containing a point mutation at amino acid 706 [(Cys $\rightarrow$ Phe), GST-RB706(C:F)]; (3) GST-MyoD (amino acids 3-318 of the MyoD protein, GST-MyoD); (4) full-length GSTId-2 (GST-Id-2); and (5) GST alone (GST). The bound proteins were analyzed by SDS-PAGE and autoradiography. The migration of E2F-1 polypeptides is indicated.

binding seems to be necessary for the myogenic activity and the growth-inhibitory effect of $\mathrm{MyoD} / \mathrm{Gu}$ et al. 1993). To compare the efficiency of the binding of MyoD and Id-2 to $\mathrm{pRb}$ in our experimental system, we examined the in vitro binding efficiency of several different protein combinations (Fig. 9). Purified GST-Id-2, GSTMyoD, or GST-Id-2[ $\Delta \mathrm{HLH}]$ fusion proteins were incubated with in vitro-translated wild-type $\mathrm{pRb}$ or the $\mathrm{mu}$ tant $\mathrm{pRb} 706$ (Cys $\rightarrow$ Phe) derived from a human tumor and containing a point mutation within the pocket that abolishes binding to the viral oncoproteins SV40 large T and E1 A (Kaye et al. 1990; Kratzke et al. 1992) and to the cellular factors E2F-1 (Helin et al. 1992; Kaelin et al. 1992) and cyclin D (Dowdy et al. 1993; Ewen et al. 1993). These experiments, shown in Figure 9, demonstrate comparable binding efficiency of GST-Id-2 and GSTMyoD to wild-type pRb. Conversely, no binding is seen between the point mutant $\mathrm{pRb} 706$ (Cys $\rightarrow$ Phe) and GST-Id-2 or GST-MyoD, thus confirming the requirement for an intact and functional pocket domain in the binding of $\mathrm{pRb}$ to HLH proteins (Gu et al. 1993). Because earlier experiments showed that the GST-Id-2[DHLH] fusion protein was not able to bind any form of $\mathrm{pRb}$ (see above), we tested whether the HLH region of the Id-2 protein was sufficient to bind to the $\mathrm{pRb}$ protein. As shown in Fig. 10, in vitro-translated wild-type $p R b$ is able to bind GST-Id-2[HLH] containing only the HLH domain, amino acids $35-76$, of the Id-2 protein. Thus, the HLH domain is necessary and sufficient for binding of Id-2 to $\mathrm{pRb}$.

\section{$A$ complex between $I d-2$ and $p R b$ exists in transfected SAOS-2 cells}

The results above suggest that the binding between Id-2 and $\mathrm{pRb}$ in vitro occurred via the same domains of Id-2 and $\mathrm{pRb}$ mediating other associations physiologically significant for these proteins (Benezra et al. 1990; Weinberg 1991). We sought to determine whether the Id-2/ $\mathrm{pRb}$ interaction found in vitro could also be seen in vivo. The identification of specific cellular proteins that complex with $\mathrm{pRb}$ in vivo has been particularly challenging, possibly because $\mathrm{pRb}$-containing complexes are unstable or because of the transient nature of these associations

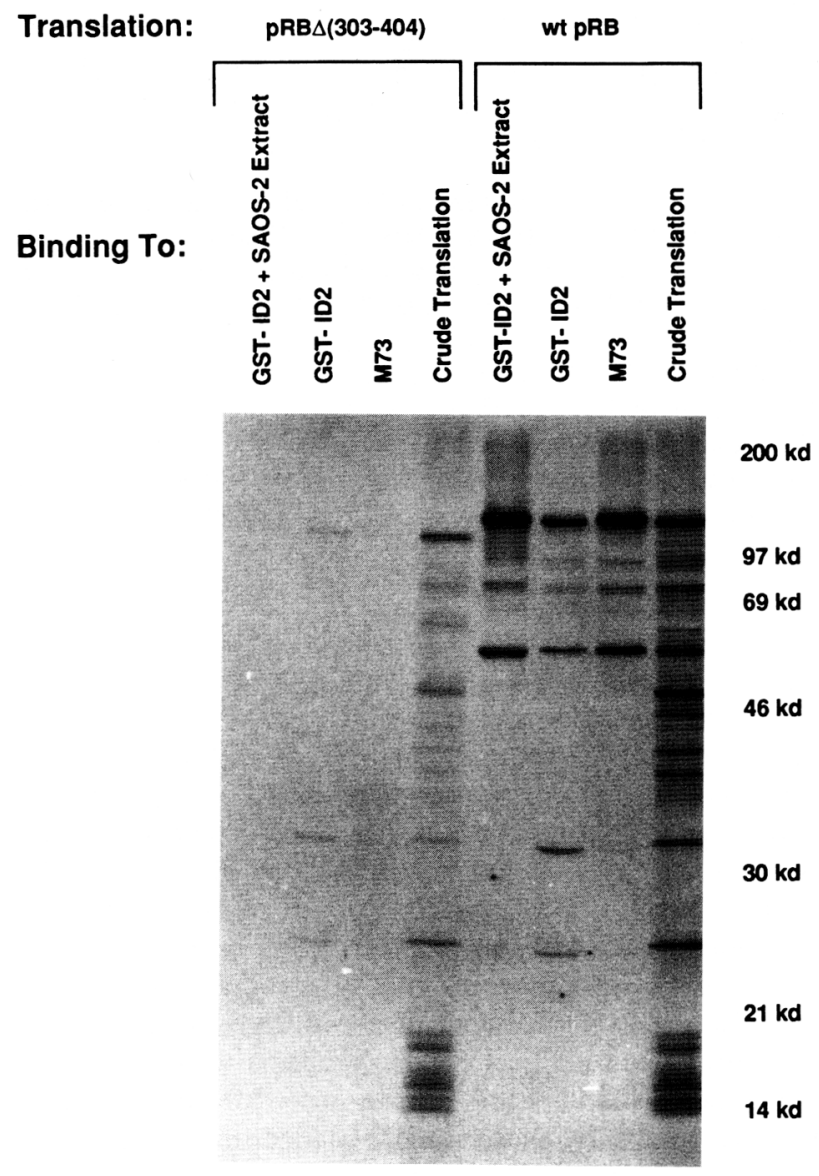

Figure 8. In vitro-translated $\mathrm{pRb}$ binds GST-Id-2. In vitrotranslated ${ }^{35}$ S-labeled wild-type $\mathrm{pRb}$ (wt $\mathrm{pRb}$ ) or mutant $\mathrm{pRb}$ containing a deletion, including amino acids 303-404 [pRB $\Delta(303-404)]$, was incubated with GST-Id-2 bound to glutathione-Sepharose in the absence (GST-ID2) or in the presence of SAOS-2 cell extracts (GST-ID2 + SAOS-2 Extract). M73 indicates the immunoprecipitation with the anti-ElA antibody M73 from a mixture of ${ }^{35} \mathrm{~S}$-labeled $\mathrm{pRb}$ translation products and an unlabeled cell extract from the cell line 293. The bound proteins were analyzed by SDS-PAGE and autoradiography. 


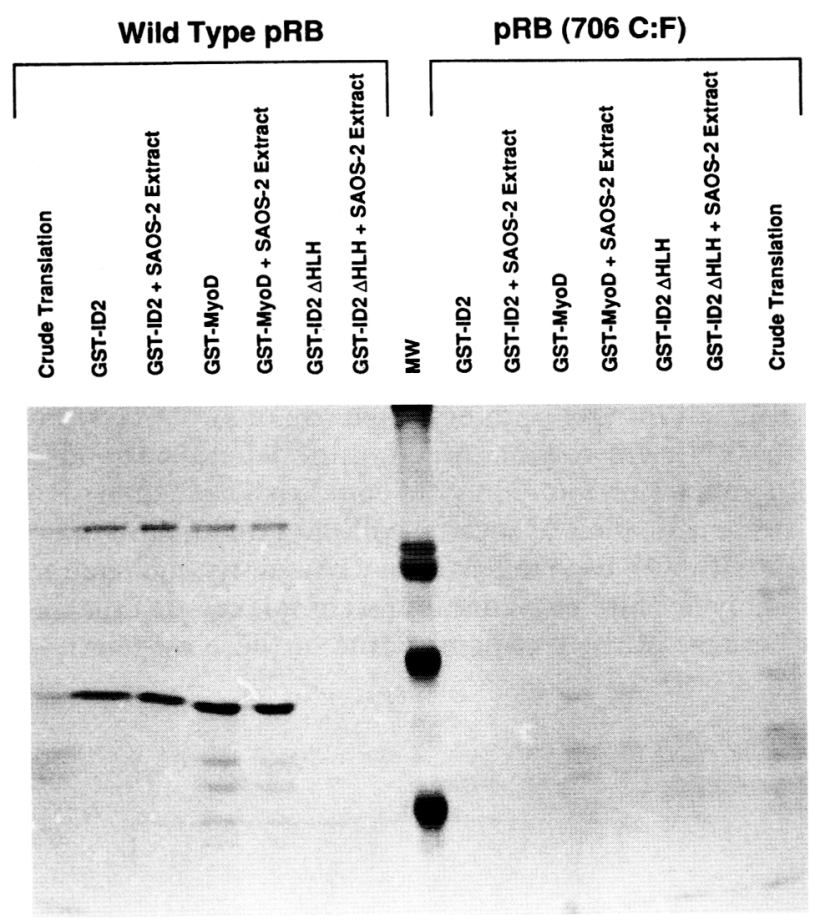

Figure 9. Specificity of binding of HLH proteins to in vitrotranslated $\mathrm{pRb}$. In vitro-translated ${ }^{35} \mathrm{~S}$-labeled wild-type $\mathrm{pRb}$ (Wild Type $\mathrm{pRb}$ ) or mutant $\mathrm{pRb}$ containing a point mutation at amino acid 706 [Cys $\rightarrow$ Phe, pRb (706 C:F)] was incubated with fusion proteins GST-Id-2 (GST-ID2), GST-MyoD (GSTMyoD), or GST-Id-2 lacking the HLH domain (GST-ID2AHLH) that were bound to glutathione-Sepharose, in the absence or in the presence of SAOS-2 cell extracts. The bound proteins were analyzed by SDS-PAGE and autoradiography. (MW) ${ }^{14} \mathrm{C}$-Labeled molecular mass markers $(200,97,69$, and $46 \mathrm{kD})$.

(Helin et al. 1992; Ewen et al. 1993; Kato et al. 1993). In addition, the conditions used to extract $\mathrm{pRb}$ and its candidate partner may not be optimal for both proteins. For instance, the efficient extraction of Id-2 from SAOS-2 cells requires the use of a buffer containing low concentrations of an ionic detergent such as SDS (e.g., RIPA buffer). These conditions are known to disrupt the hydrophobic, noncovalent interactions commonly involved in nuclear protein-protein associations.

To detect Id $2 / \mathrm{pRb}$ complexes in vivo, we attempted to coimmunoprecipitate these proteins with a recently developed in vivo cross-linking procedure using the reversible lipophilic agent dithiobis/succinimidyl propionate) (DSP) in SAOS-2 transiently transfected with $I d-2$ and $R B$ (Maheswaran et al. 1993, 1994). As shown in Table 2, this is an experimental condition in which Id-2 and $\mathrm{pRb}$ display a specific functional antagonism. Fortyeight hours after cotransfection with Id-2 and pRb expression vectors, SAOS-2 cells were labeled with $\left[{ }^{35}\right.$ S $]$ methionine and $\left[{ }^{35} \mathrm{~S}\right]$ cysteine and treated with DSP before lysis in RIPA buffer. Lysates from cross-linked cells were immunoprecipitated with either anti-pRb or anti-Id-2 antibodies. Following incubation with dithio- threitol (DTT), an aliquot of these immunoprecipitates was separated by SDS-PAGE. Id-2 and $\mathrm{pRb}$ immunoprecipitated from cross-linked extracts had the same size as those immunoprecipitated from SAOS- 2 extracts in the absence of cross-linker (Fig. 11, lane 2; data not shown). In the presence of DSP, a band of $15 \mathrm{kD}$ comigrating with Id-2 was seen in the pRb immunoprecipitates (Fig. 11, lane 1) but it was absent in an immunoprecipitation from normal rabbit immunoglobulins (NRIg, Fig. 11, lane 3). To confirm the identity of this band, the immunocomplexes were boiled in the presence of $2 \%$ SDS and the released proteins were reimmunoprecipitated with anti-Id- 2 antibodies. A band comigrating with Id- 2 was precipitated with anti-Id- 2 antibodies from the immunocomplexes initially isolated with anti-pRb antibodies (Fig. 11, lane 5) but not from control immunocomplexes (Fig. 11, lane 4). We have also observed these complexes using the anti-pRb mouse mAb XZ77 (data not shown).
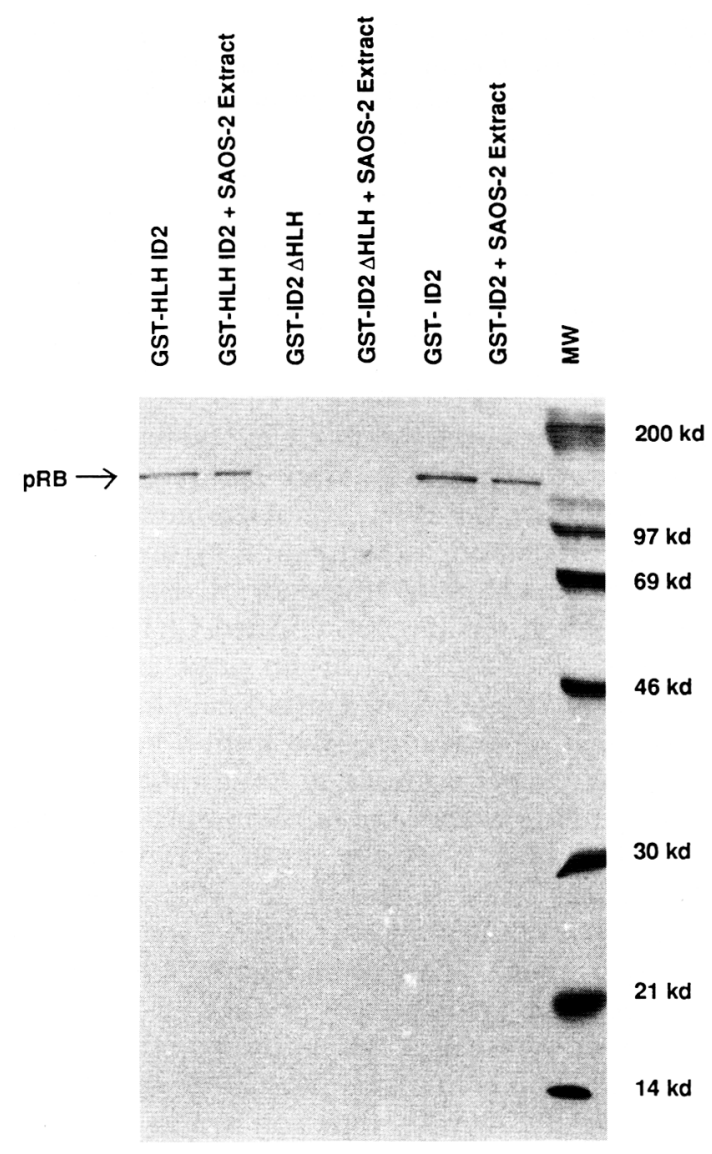

Figure 10. The HLH domain of Id-2 mediates interaction with $\mathrm{pRb}$. In vitro-translated ${ }^{35} \mathrm{~S}$-labeled wild-type $\mathrm{pRb}(\rightarrow)$ was incubated with constructs of GST-Id-2 containing (1) the HLH domain of Id-2 (GST-HLHID2), (2) full-length GST-Id-2 (GSTID2), or (3) GST-Id-2 lacking the HLH domain (GST-ID2 $\Delta H L H$ ) that were bound to glutathione-Sepharose, in the absence or in the presence of SAOS- 2 cell extracts. Bound proteins were analyzed by SDS-PAGE and autoradiography. (MW) ${ }^{14} \mathrm{C}$-Labeled molecular mass markers (in $\mathrm{kD}$ ). 


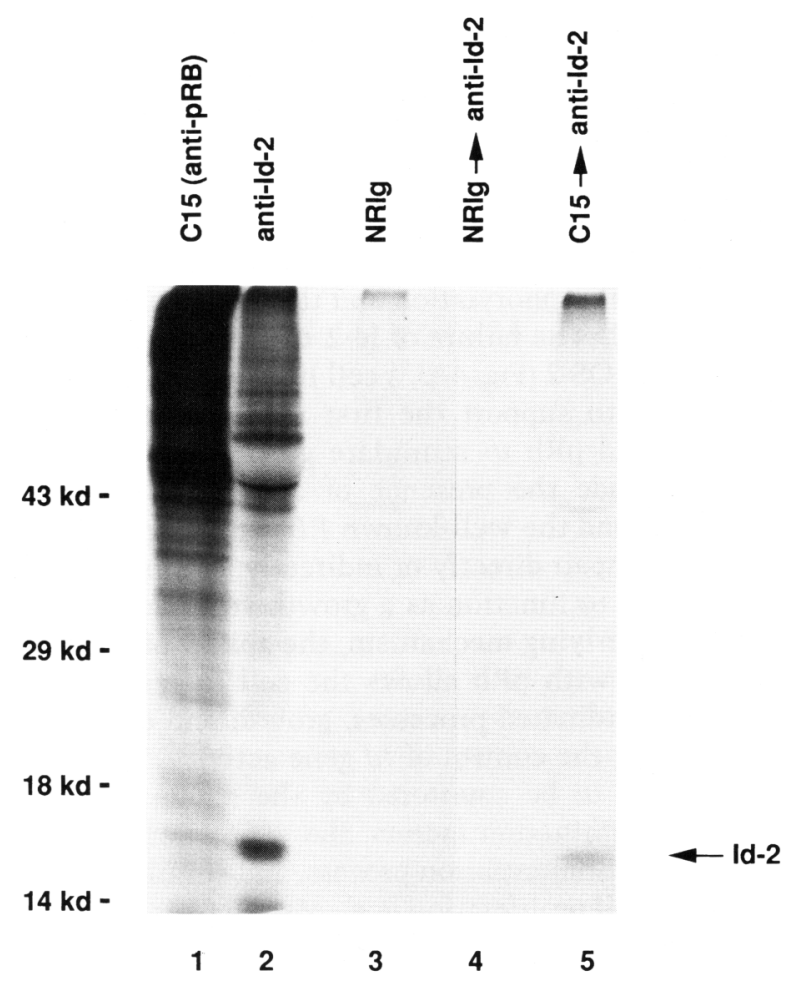

Figure 11. In vivo association between Id-2 and pRb. SAOS-2 cells transiently transfected with $\mathrm{pRb}$ and Id-2 expression vectors were metabolically labeled with $\left[{ }^{35} \mathrm{~S}\right]$ methionine and $\left[{ }^{35} \mathrm{~S}\right]$ cysteine and treated with the cross-linking agent DSP before lysis with RIPA buffer. The lysates were immunoprecipitated with antibodies against $\mathrm{pRb}(\mathrm{C} 15$, lane 1$)$, against Id-2 (lane 2), or with normal rabbit immunoglobulins (NRIg, lane 3). The reduced complexes from the immunoprecipitations with NRIg and C15 were boiled in 2\% SDS and diluted for reimmunoprecipitation with anti-Id-2 antibodies (lane 4 and lane 5, respectively|. Immunoprecipitates were boiled in the presence of $0.2 \mathrm{M}$ DTT and separated on a $12.5 \%$ SDS-polyacrylamide gel. Lanes 1-3 were noncontiguous to lanes 4-5 in a single gel on which these five samples were loaded.

\section{Discussion}

\section{Id-2 expression enhances proliferation}

Our data indicate that the constitutive expression of the HLH protein Id-2 enhances the growth of the human osteosarcoma cell line U2OS. Overexpressed Id-2 in the cell line U2OS functions to inhibit differentiation. When U2OS(Id-2) cells are treated with the differentiating agent 1,25-dihydroxyvitamin D3, the activity of the osteogenic differentiation marker alkaline phosphatase is only $50 \%$ of that found in U2OS(pMEP4) (data not shown). Cells overexpressing Id-2 have a faster growth rate than normal controls and are characterized by a larger proportion of the population in the $\mathrm{S}$ phase of the cell cycle. They also show less dependence on serum for growth (Fig. 2). These changes indicate the acquisition of an enhanced growth potential conferred by Id-2 overexpression in these cells. The hypothesis that Id proteins could have a role in cell proliferation and cell cycle reg- ulation was proposed initially for the protein expressed from the mouse gene $H L H 462$, also known as Id-3 (Christy et al. 1991). This gene is induced in mouse 3T3 cells as part of the immediate early transcriptional response to growth factors (Christy et al. 1991). Similarly, its human homolog $1 R 21$ is an early response gene inducible by phorbol esters (Deed et al. 1993). Our data identify growth regulation as a function of Id-2 and raise the likely possibility that other Id proteins will also function as positive growth regulators.

It is now well established that suppression of $I d$ gene activity is a prerequisite for the normal process of cell differentiation (Benezra et al. 1990). In several different cell types, the down-regulation of Id gene expression preceding the onset of cell differentiation is associated with cells entering a quiescent state even in the presence of high levels of mitogens (Benezra et al. 1990; Sun et al. 1991; Zentella and Massague 1992). These findings are consistent with the conclusion that a high level of Id expression can inhibit differentiation and, at the same time, maintain the proliferative state of cells. In this model, down-regulation of Id expression is required not only to allow cell type-specific transcription but also to mediate the cell cycle arrest that is typically associated with cell differentiation.

\section{Functional antagonism and specific binding of Id-2 and $p R b$}

In mammalian cells, key regulators for cell cycle control are found late in $\mathrm{G}_{1}$ (Pardee 1989). One of these regulators, $\mathrm{pRb}$, fluctuates during the cell cycle between an active, underphosphorylated form and an inactive, more heavily phosphorylated form (Buchkovich et al. 1989). Unphosphorylated $\mathrm{pRb}$ is present in the $\mathrm{G}_{0}$ and early $\mathrm{G}_{1}$ phases of the cell cycle and becomes hyperphosphorylated in late $G_{1}$. The phosphorylation of $p R b$ by specific kinases is required for the progression of the cell into $S$ phase (Goodrich et al. 1991; Lees et al. 1991). The experiments evaluating growth suppression and cell cycle arrest by pRb shown in Tables 1 and 2 demonstrate that Id-2 can specifically target the pRb-mediated arrest of cell proliferation rescuing SAOS-2 cells from the block of entry into $S$ phase produced by $\mathrm{pRb}$. We propose that this effect is mediated by the binding of Id-2 to the unphosphorylated form of $\mathrm{pRb}$ seen in vitro and in vivo. A mutant of Id-2 lacking the HLH domain loses both its ability to bind $\mathrm{pRb}$ and to rescue $\mathrm{pRb}$-mediated growth arrest. These findings are consistent with the close correlation between the ability of the viral oncoproteins to bind $\mathrm{pRb}$ and to enhance cellular proliferation (Dyson and Harlow 1992). Id-2 does not appear to inactivate $\mathrm{pRb}$ function by causing its hyperphosphorylation. The physical occupation of the $\mathrm{pRb}$ pocket by Id-2 is a more likely mechanism for this inactivation. Our data indicate a functional parallelism between the function of Id-2 and the role of cyclin D1 in promoting cell cycle progression. This cyclin can regulate $\mathrm{pRb}$ function by binding to unphosphorylated $\mathrm{pRb}$, and like Id-2, it does not induce $\mathrm{pRb}$ phosphorylation (Dowdy et al. 1993). 
The domains mediating the interaction between Id-2 and $\mathrm{pRb}$ (the $\mathrm{HLH}$ region of $\mathrm{Id}-2$ and the pocket binding domain of $\mathrm{pRb}$ ) are also the domains known to be involved in other protein-protein interactions important for the biologic functions of these molecules (Kaelin et al. 1991; Pesce and Benezra 1993). This is consistent with the behavior of the mutations that we have analyzed in both the binding sites of Id-2 and pRb. Inactivation of $\mathrm{pRb}$ by mutation, phosphorylation, or binding to either viral or cellular proteins would be predicted to prevent Id- 2 binding and the functional consequences of this association. In view of the evidence identifying Id-2 as a functional antagonist of $\mathrm{pRb}$, our results strongly suggest that $\mathrm{pRb}$-mediated growth suppression is a direct and specific target of Id- 2 . The binding of Id-2 to $\mathrm{pRb}$ described here may be a mechanism by which Id-2 mediates the activation of cell proliferation in vivo.

\section{Id proteins in cell growth}

The initial model proposed for Id function (Benezra et al. 1990 ) suggested that high levels of Id were necessary to inhibit the expression of the terminal differentiation program by titrating the available pool of ubiquitous bHLH factors, E12/E47. In the presence of an appropriate differentiating stimulus, Id down-regulation would allow the formation of active complexes between ubiquitous and tissue-specific bHLH transcription factors, thereby activating lineage-specific gene transcription and differentiation. However, this model does not explain the simultaneous switch from the proliferative state to a nonproliferative state typically associated with differentiation. Our data suggest that when the level of Id-2 is high, not only is Id-2 complexed with ubiquitous bHLH proteins to inhibit differentiation, but it is also complexed with $\mathrm{pRb}$ to allow cellular proliferation. Conversely, the down-regulation of Id expression enables bHLH factors to dimerize and bind DNA, initiating differentiation. Simultaneously, the interaction between Id and $\mathrm{pRb}$ is disrupted, allowing $\mathrm{pRb}$ to exert its growth-suppressive activity. This model proposes a molecular mechanism linking two biologically coordinated phenomena, expression of the undifferentiated phenotype and proliferation, involving the binding of Id-2 to diverse cellular proteins.

What is the mechanism by which Id-2 inhibits the growth-suppressive function of $\mathrm{pRb}$ ? $\mathrm{pRb}$ does not seem to inhibit growth by directly binding DNA; however, it can negatively regulate cell cycle progression by binding a series of growth-promoting proteins, including the transcription factor E2F and D-type cyclins. This binding occurs via the pocket domain of $\mathrm{pRb}$ and is specific for the hypophosphorylated form of pRb. Similarly, an intact pocket in $\mathrm{pRb}$ is required for Id-2 binding, and the interaction between Id-2 and $\mathrm{pRb}$ is restricted to unphosphorylated pRb. Such an association between Id-2 and $\mathrm{pRb}$ is compatible with two quite distinct but not mutually exclusive models. On one hand, this binding may indicate a viral oncoprotein-like role for Id-2 in which it binds most of the $\mathrm{pRb}$ in the cell, thereby inhibiting the ability of $\mathrm{pRb}$ to associate with and to inactivate growth- promoting cellular proteins like E2F and D-cyclins (Hinds et al. 1992; Zhu et al. 1993). On the other hand, this association may point to the control of Id-2 activity by $\mathrm{pRb}$ binding. When released from the association with $\mathrm{pRb}$, Id- 2 may be free to antagonize the action of an endogenous growth-suppressing bHLH transcription factor. This mechanism could operate at the $G_{1} / S$ interface following $\mathrm{pRb}$ phosphorylation and the consequent release of bound Id-2. The failure of Id-2 to enhance cell proliferation in SAOS-2 (Fig. 4A), a cell line lacking functional $\mathrm{pRb}$, seems to support the first model in which Id-2 needs to bind $\mathrm{pRb}$ to stimulate growth. However, we cannot exclude the presence of additional defects in SAOS- 2 beyond the well-known $R B$ gene rearrangement that could impair directly or indirectly the ability of exogenous Id-2 to function as a growth stimulator. Whatever the underlying mechanism, the ability of an Id protein to bind with $\mathrm{pRb}$ allows the cell to regulate two typically coordinated processes, growth and differentiation, through the control of $I d$ gene activity. This strategy is likely to be countered by the action of tissuespecific determination factors, the expression of which initiates the differentiation process, and simultaneously, suppresses cell proliferation (e.g., MyoD, Crescenzi et al. 1990; Sorrentino et al. 1990).

\section{Materials and methods}

plasmids

The complete coding sequence of human Id-2 was excised from plasmids (Biggs et al. 1992) and cloned into the HindIII and BamHI sites of the mammalian expression vector pMEP4 to prepare the construct pMEP4(Id-2). A PCR-amplified fragment containing the complete coding sequence of human $I d-2$ with artificial BamHI sites on both ends was subcloned into the unique BamHI site of the pCMV-Neo-Bam vector (Baker et al. 1990). The orientation of Id- 2 sequences in the resulting vectors, pCMVId-2 (with Id-2 in the sense orientation) and pCMVId-2AS (with Id-2 in the antisense orientation), was determined by restriction digestion mapping and DNA sequencing.

To prepare Id-2 fusion protein with GST, the full length $B a m H I-B a m H I$ fragment of $I d-2$-coding sequence from pCMVId-2 was cloned in-frame into the BamHI site of the expression vector pGEX-2T (Pharmacia) to give pGST-Id-2. The vector pGST-Id-2[ $\triangle \mathrm{HLH}]$, lacking the entire HLH domain (codons 3576) of human Id-2, was derived from pGST-Id-2 by a sequential PCR scheme as described previously (Higuchi et al. 1988). In PCR reaction A, pGST-Id-2 was amplified using 5'-CTATGGCCATCATACGTTATATAG-3' as the upstream primer and 5'-GGATGCGAGTCCAGGGCGATGCTCATCGGGTCGTCCACAG-3' as the downstream primer from which a 598-bp amplified fragment was obtained. In PCR reaction B, pGST-Id-2 was amplified using 5'-CTGTGGACGACCCGATGAGCATCGCCCTGGACTCGCATCC-3' and 5'-GGGGGATCCTCAGCCACACAGTGCTTTGCT- $3^{\prime}$ as the upstream and downstream primers, respectively, to give a 205-bp fragment. Aliquots of each PCR product were purified following agarose gel electrophoresis and combined to serve as a template for a final PCR using the PCR A upstream primer and the PCR B downstream primer. The 783-bp PCR product from this reaction was digested with $B a m H I$, and a $B a m H I-B a m H I$ fragment of $279 \mathrm{bp}$ was subcloned into the BamHI site of pGEX-2T and 
into the BamHI site of the pCMV-Neo-Bam vector [pCMVId$2 \Delta \mathrm{HLH}$. To generate the recombinant pGST-Id-2[HLH], the HLH domain of Id- 2 was obtained by amplification of a fragment including codons 35-76 of human Id-2 and directionally subcloned in the BamHI and EcoRI sites of pGEX-2T.

The plasmids HußAcpr-1-neo-PQ (herein referred as $\mathrm{p} \beta A$ Actvector) and its $R B$ derivative (p $\beta A c t R B)$ were obtained from Y.-K. T. Fung [Childrens Hospital Los Angeles, CA (Fung et al. 1993|]. The plasmid pSP72-E2F1, expressing E2F-1 mRNA from a SP6 promoter, was obtained from W.G. Kaelin [DanaFarber Cancer Institute, Boston, MA (Kaelin et al. 1992)]. The plasmids pGEM4-wtRB, pGEM4-H209RB, pGEXwtRB|379928), and pGEX209RB(379-928), obtained from F.J. Kaye (National Cancer Institute, Bethesda, MD), have been described (Kratzke et al. 1992). The plasmid RBA(303-404) was obtained from Q. Hu [University of California at San Francisco (Hu et al. 1990)]. The plasmid encoding GST-MyoD(3-318) was obtained from $\mathrm{H}$. Weintraub [Fred Hutchinson Cancer Center, Seattle, WA (Lassar et al. 1989)]. The plasmid pCMVCD20 was obtained from E. Harlow [Massachusetts General Hospital, Boston, MA [Zhu et al. 1993)].

\section{Cell culture, transfection, and Id-2 immunoprecipitation}

The human osteosarcoma cell lines U2OS and SAOS-2 were obtained from ATCC, and 293 cells, a human embryonic cell line transformed by a fragment of the adenovirus 5 genome, were obtained from W.G. Kaelin and D.M. Livingston (DanaFarber Cancer Institute, Boston, MA). All cells were grown in Dulbecco's modified Eagle's medium (DMEM) with 10\% FCS (GIBCO). Stable transformants from U2OS or SAOS-2 were prepared using a modified calcium phosphate precipitation technique (Chen and Okayama 1987) with transfection of $30 \mu \mathrm{g}$ of input plasmid DNA per 100-mm dish and selection for 3 weeks in complete culture medium containing $200 \mu \mathrm{g} / \mathrm{ml}$ of hygromycin B (Calbiochem) or $600 \mu \mathrm{g} / \mathrm{ml}$ of G418 (Geneticin, GIBCO), respectively. All subsequent experiments involving the use of transfected cell lines were done in the presence of hygromycin B or G418.

To immunoprecipitate Id-2 protein from U2OS transfectants, $1 \times 10^{6}$ exponentially growing cells were metabolically labeled in $100-\mathrm{mm}$ dishes for $4 \mathrm{hr}$ at $37^{\circ} \mathrm{C}$ in $2 \mathrm{ml}$ of DMEM lacking methionine and cysteine (GIBCO) containing $0.5 \mathrm{mCi}$ of ${ }^{35} \mathrm{~S}$ EXPRESS Protein Labeling Mix (NEN-Du Pont). Labeled cells were lysed for $30 \mathrm{~min}$ on ice in $1 \mathrm{ml}$ of EBC buffer $150 \mathrm{~mm}$ Tris- $\mathrm{HCl}$ at $\mathrm{pH} 8.0,120 \mathrm{~mm} \mathrm{NaCl}, 0.5 \% \mathrm{NP}-40,1 \mathrm{~mm}$ EDTA) containing $10 \mu \mathrm{g} / \mathrm{ml}$ of aprotinin and leupeptin and $1 \mathrm{mM}$ PMSF (Sigma). Lysates were clarified by centrifugation, and aliquots of the cleared supernatants $(0.5 \mathrm{ml})$ were incubated for $1 \mathrm{hr}$ at $4^{\circ} \mathrm{C}$ with antiserum against Id-2 or preimmune serum. After incubation for $1 \mathrm{hr}$ at $4^{\circ} \mathrm{C}$ with protein A-Sepharose beads (Pharmacia), immunoprecipitates were collected by centrifugation, washed five times with $\mathrm{EBC}$ buffer at $4^{\circ} \mathrm{C}$, and denaturated in SDS loading buffer for electrophoresis. Samples were separated on $15 \%$ SDS-PAGE and visualized by autoradiography. Rabbit polyclonal antibodies to Id-2 were prepared by standard immunization procedure using GST-Id-2 fusion protein from preparative SDS-PAGE as the immunogen (Harlow and Lane 1988).

Growth rate, serum dependence, and cell cycle analysis in stable transfectants

To determine the growth rate of stable transfectants from U2OS and SAOS-2, cells were seeded in six-well plates in complete medium. Medium was changed every three days. Triplicate cul- tures were counted at daily intervals by hemocytometer, and cell viability was determined by trypan blue exclusion. For the serum dependence experiments, U2OS(pMEP4) and U2OS(Id-2) cells were plated in six-well plates at a density of $10^{5}$ cells/well in complete medium and allowed to attach. Twelve hours after plating, the medium was removed, cells were washed twice with serum-free medium, and fresh medium containing various concentrations of serum $(10 \%, 1 \%$, or $0.1 \% \mathrm{FCS})$ was added. The medium was changed every 3 days. Cells were counted and cell viability was assessed by trypan blue exclusion. For flow cytometric analysis, U2OS(pMEP4) and U2OS(Id-2) cells in exponential growth were labeled with $10 \mu \mathrm{M} \mathrm{BrdU}$ (Sigma) for $2 \mathrm{hr}$, detached by trypsinization, diluted $1: 1$ in complete medium, and collected by centrifugation at room temperature. Cells were washed once with PBS, fixed for $2 \mathrm{hr}$ at $4^{\circ} \mathrm{C}$ in $70 \%$ ethanol, and permeabilized at $4^{\circ} \mathrm{C}$ for $10 \mathrm{~min}$ in $0.1 \mathrm{M} \mathrm{HCl}$ and $0.5 \%$ Triton $\mathrm{X}-100\left(1 \mathrm{ml} / 10^{6}\right.$ cells $)$. After two more washes with PBS, cells were incubated for $30 \mathrm{~min}$ at room temperature with anti-BrdU antibodies conjugated to fluorescein (FITC, Boehringer Mannheim, 1:20 dilution) in PBS. Cells were finally resuspended in PBS containing $50 \mu \mathrm{g} / \mathrm{ml}$ of RNase (Sigma) and $5 \mu \mathrm{g} / \mathrm{ml}$ of propidium iodide (Boehringer Mannheim), and they were filtered through Nitex mesh (Tetco, Inc.) immediately before analysis by flow cytometry (Becton Dickinson FACScan and Lysis II software).

\section{Colony formation assay, S-phase analysis, and Western blot of $p R b$ in transfected SAOS-2 cells}

Transfections for the colony suppression assay were performed using DNA precipitated with calcium phosphate as described previously (Qin et al. 1992). SAOS-2 cells at $\sim 70 \%$ confluence were transfected with $20 \mu \mathrm{g}$ of $p \beta A c t v e c t o r$ or $\mathrm{p} \beta A \mathrm{ActRB}$ DNA plus $20 \mu \mathrm{g}$ of pCMVId-2AS or pCMVId-2 DNA. Forty-eight hours after transfection, cells were split 1:8 into medium containing $600 \mu \mathrm{g} / \mathrm{ml}$ of G418, and 18 days later colonies were stained and counted under the microscope. To analyze the fraction of transfected cells in S phase, we used a double immunofluorescence technique to detect $\mathrm{CD} 20$ and $\mathrm{BrdU}$, modified from a protocol described previously (Zhu et al. 1993). SAOS-2 were transfected with $15 \mu \mathrm{g}$ of each plasmid indicated in Table 2 plus $5 \mu \mathrm{g}$ of pCMVCD20. Twenty-four hours after the removal of DNA precipitates, cells were trypsinized and cultured for 24 $\mathrm{hr}$ in tissue culture chamber slides (Nunc) at a density of $10^{5}$ cells/chamber. Cells were labeled with BrdU $(10 \mu \mathrm{M})$ for $2 \mathrm{hr}$, washed, and incubated on ice for $30 \mathrm{~min}$ in medium $(200 \mu \mathrm{l})$ chamber/ containing a 1:10 dilution of a phycoerytrin-conjugated anti-CD20 antibody (Becton-Dickinson). After washing, cells were fixed overnight at room temperature in PBS containing $1 \%$ paraformaldehyde and $0.01 \%$ Tween 20 . The simultaneous analysis of CD20 and BrdU was performed as described previously (Carayon and Bord 1992). Briefly, cells were incubated for $30 \mathrm{~min}$ at $37^{\circ} \mathrm{C}$ in PBS with 250 Kunitz units $/ \mathrm{ml}$ of pancreatic DNase I (Boehringer Mannheim). After washing, cells were exposed to PBS with $0.5 \%$ Tween -20 containing a $1: 20$ dilution of anti-BrdU antibodies conjugated to fluorescein. After $45 \mathrm{~min}$ of incubation, slides were washed, mounted, and analyzed under a Zeiss fluorescence microscope. Approximately 300 phycoerytrin-positive cells were counted, and the fraction of cells that were also positive for FITC was determined for each sample. For Western blot analysis, protein lysate was prepared from $1 \times 10^{6}$ SAOS- 2 cells $48 \mathrm{hr}$ after transfection, boiled in SDS loading buffer, and separated on 6\% SDS-PAGE. Proteins were transferred to a nitrocellulose filter, the filter was blocked in $5 \%$ nonfat milk, and incubated with $1 \mu \mathrm{g} / \mathrm{ml}$ of the anti-pRb antibody C-15 (Santa Cruz Biotech.) in PBS-T (PBS/ 
$0.1 \%$ Tween-20) for $1 \mathrm{hr}$. After three washes in PBS-T, the filter was incubated in a $1: 10,000$ dilution of IgG conjugated to horseradish peroxidase (GIBCO) in PBS-T for $1 \mathrm{hr}$. The filter was washed, developed by chemiluminescence (ECL, Amersham), and exposed to film.

\section{Immunofluorescence staining of Id-2 and $p R b$ in transfected SAOS-2 cells}

SAOS- 2 cells were transfected as described above with different combinations of expression vectors, trypsinized, and cultured in tissue culture chamber slides. For double immunofluorescence of Id-2 and pRb, the cells were fixed in $4 \%$ paraformaldehyde in PBS for $10 \mathrm{~min}$ at room temperature and permeabilized with methanol/acetone $(1: 1)$ for $30 \mathrm{sec}$ at room temperature. The nonspecific binding sites were blocked by incubating the cells in PBS-T containing 10\% goat serum (Zymed) plus $3 \%$ bovine serum albumin. This solution was also used for the following incubations with various antibodies. The first incubation was with $20 \mu \mathrm{g} / \mathrm{ml}$ of rabbit polyclonal anti-Id-2 antibodies (IgG purified by protein A), and the second incubation was with 10 $\mu \mathrm{g} / \mathrm{ml}$ of mouse monoclonal anti-pRb antibody pMG3-245 (PharMingen). Each 1-hr incubation was carried out sequentially at room temperature. After washing in PBS-T, cells were incubated for $1 \mathrm{hr}$ at room temperature with a solution containing rhodamine-conjugated goat anti-rabbit IgG (Boehringer Mannheim, final dilution 1:500) and FITC-conjugated goat antimouse IgG (Boehringer Mannheim, final dilution 1:50). Cells were finally washed and mounted before the double-stained preparations were examined and photographed.

\section{In vitro binding assay}

Expression and purification of GST fusion proteins were performed as described previously (Kaelin et al. 1991). Lysates made from $1 \times 10^{6}$ SAOS- 2 or U2OS cells were incubated with glutathione-Sepharose beads (Pharmacia) containing 2-3 $\mu \mathrm{g}$ of GST fusion proteins in $0.5 \mathrm{ml}$ of EBC buffer in the presence of protease inhibitors for $2 \mathrm{hr}$ at $4^{\circ} \mathrm{C}$. Where reported, $0.1 \mathrm{mM} \mathrm{NaF}$ and $0.2 \mathrm{mM} \mathrm{Na}_{3} \mathrm{VO}_{4}$ were included as phosphatase inhibitors in the preparation of the lysates. Beads were then washed five times with $E B C$ and bound proteins were released by boiling in SDS loading buffer and separated on SDS-PAGE. Immunoprecipitation with the anti-pRb antibody C36 (Oncogene Science) or the anti-ElA antibody M73 (Oncogene Science) was performed as described for the immunoprecipitation of Id-2, using unlabeled cells. Following fractionation by PAGE, immunoprecipites were transferred to nitrocellulose for Western blot analysis with anti-pRb antibody C-15 or G99-549 (PharMingen).

${ }^{35} \mathrm{~S}$-labeled polypeptides were prepared from linearized plasmid DNA by in vitro transcription and translation using $\left.{ }^{35} S\right]$ methionine (Amersham) and a rabbit reticulocyte translation kit as recommended by the supplier (Promega). EBC buffer $(0.5 \mathrm{ml})$ or cell lysates prepared in EBC from SAOS-2 or 293 las source of ElA oncoprotein) was mixed with $15 \mu \mathrm{l}$ of ${ }^{35} \mathrm{~S}$-labeled in vitro-translated polypeptides and incubated for $30 \mathrm{~min}$ at $4^{\circ} \mathrm{C}$. Beads containing GST fusion proteins were then added and incubated for $2 \mathrm{hr}$. Alternatively, immunoprecipitation was performed with the anti-E1A antibody M73. After washing, proteins were boiled in SDS loading buffer, separated on SDSPAGE, and visualized by autoradiography.

\section{SAOS-2 cross-linking and coimmunoprecipitations}

SAOS-2 cells were transfected with $20 \mu \mathrm{g}$ of p $\beta$ ActRB DNA plus $20 \mu \mathrm{g}$ of pCMVId-2 DNA and cultured for $48 \mathrm{hr}$ after removal of
DNA precipitates. Cells were metabolically labeled with ${ }^{35} \mathrm{~S}$ EXPRESS Protein Labeling Mix as described above and incubated for $30 \mathrm{~min}$ at room temperature with the cross-linking agent DSP (Pierce; $100 \mathrm{mg} / \mathrm{ml}$ of stock in dimethylsulfoxide) at a final concentration of $3 \mathrm{~mm}$ in PBS. The cross-linking reaction was terminated by the addition of Tris $-\mathrm{HCl}(\mathrm{pH} 7.7)$ at a final concentration of $0.1 \mathrm{M}$, proteins were extracted at $4^{\circ} \mathrm{C}$ with RIPA buffer (50 mM Tris- $\mathrm{HCl}$ at $\mathrm{pH} 7.7,150 \mathrm{~mm} \mathrm{NaCl}, 1 \%$ NP- $40,0.5 \%$ sodium deoxycholate, $0.1 \%$ SDS) containing protease inhibitors. Immunoprecipitations were performed by incubating the cross-linked lysates for $1 \mathrm{hr}$ at $4^{\circ} \mathrm{C}$ with $10 \mu \mathrm{l}$ of rabbit antiserum to Id- 2 or with $1 \mu \mathrm{g}$ of either the rabbit polyclonal antibody against pRb, C-15, or control NRIg. After incubation for $1 \mathrm{hr}$ at $4^{\circ} \mathrm{C}$ with protein A-Sepharose beads, immunoprecipitates were washed four times with RIPA buffer at $4^{\circ} \mathrm{C}$, reduced with $0.2 \mathrm{M}$ DTT, and boiled in SDS loading buffer for electrophoresis. An aliquot of the samples was loaded directly on a $12.5 \%$ SDS-polyacrylamide gel and visualized by autoradiography. The remaining immunocomplexes were reimmunoprecipitated as described (Helin et al. 1992). Briefly, immunoprecipitated proteins, which had been reduced by DTT and boiled in $2 \%$ SDS to dissociate complexes, were diluted $1: 15$ by the addition of RIPA buffer. Reimmunoprecipitations were performed as indicated by the addition of $10 \mu \mathrm{l}$ of rabbit antiserum to Id-2.

\section{Acknowledgments}

We thank Dr. Qianjin Hu for his thoughtful comments and suggestions. A.I. is a Howard Hughes Medical Institute Physician Research Fellow. P.G. was a Howard Hughes Medical Institute Medical Student Research Training Fellow. A.L. is a recipient of a fellowship from the Italian Association for Cancer Research. This work was supported by grants from The Price Foundation, the Preuss Foundation, and the Betz Foundation.

The publication costs of this article were defrayed in part by payment of page charges. This article must therefore be hereby marked "advertisement" in accordance with 18 USC section 1734 solely to indicate this fact.

\section{References}

Alema, S. and F. Tato. 1987. Interaction of retroviral oncogenes with the differentiation program of myogenic cells. Adv. Cancer Res. 49: 1-28.

Baker, S.J., S. Markowitz, E.R. Fearon, J.K. Willson, and B. Vogelstein. 1990. Suppression of human colorectal carcinoma cell growth by wild-type p53. Science 249: 912-915.

Baserga, R. 1985. The biology of cell reproduction. Harvard University Press, Cambridge, MA.

Benezra, R., R.L. Davis, D. Lockshon, D.L. Turner, and H. Weintraub. 1990. The protein Id: A negative regulator of helixloop-helix DNA binding proteins. Cell 61: 49-59.

Biggs, J., E.V. Murphy, and M.A. Israel. 1992. A human Id-like helix-loop-helix protein expressed during early development. Proc. Natl. Acad. Sci. 89: 1512-1516.

Buchkovich, K., L.A. Duffy, and E. Harlow. 1989. The retinoblastoma protein is phosphorylated during specific phases of the cell cycle. Cell 58: 1097-1105.

Carayon P. and A. Bord. 1992. Identification of DNA-replicating lymphocyte subsets using a new method to label the bromodeoxyuridine incorporated into the DNA. J. Immunol. Methods 147: 225-230.

Chellappan, S.P., S. Hiebert, M. Mudryi, J.M. Horowitz, and J.R. Nevins. 1991. The E2F transcription factor is a cellular target 
for the RB protein. Cell 65: 1053-1061.

Chen, C. and H. Okayama. 1987. High-efficiency transformation of mammalian cells by plasmid DNA. Mol. Cell. Biol. 8: 2745-2752.

Chen, P.L., Y.M. Chen, R. Bookstein, and W.H. Lee. 1990. Genetic mechanisms of tumor suppression by the human $\mathrm{p} 53$ gene. Science 250: 1576-1580.

Christy, B.A., L.K. Sanders, L.F. Lau, N.G. Copeland, N.A. Jenkins, and D. Nathans. 1991. An Id-related helix-loop-helix protein encoded by a growth factor-inducible gene. Proc. Natl. Acad. Sci. 88: 1815-1819.

Crescenzi, M., T.P. Fleming, A.B. Lassar, H. Weintraub, and S.A. Aaronson. 1990. MyoD induces growth arrest independent of differentiation in normal and transformed cells. Proc. Natl. Acad. Sci. 87: 8442-8446.

Davis, R.L., P.F. Cheng, A.B. Lassar, and H. Weintraub. 1990. The MyoD DNA binding domain contains a recognition code for muscle-specific gene activation. Cell 60: 733-746.

DeCaprio, J.A., J.W. Ludlow, J. Figge, J.Y. Shew, C.M. Huang, W.H. Lee, E. Marsilio, E. Paucha, and D.M. Livingston. 1988. SV40 large tumor antigen forms a specific complex with the product of the retinoblastoma susceptibility gene. Cell 54: 275-283.

Deed, R.W., S.M. Bianchi, G.T. Atherton, D. Johnston, M. Santibanez-Koref, J.J. Murphy, and J.D. Norton. 1993. An immediate early human gene encodes an Id-like helix-loophelix protein and is regulated by protein kinase $\mathrm{C}$ activation in diverse cell types. Oncogene 8: 599-607.

Diller, L., J. Kassel, C.E. Nelson, M.A. Gryka, G. Litwak, M. Gebhardt, B. Bressac, M. Ozturk, S.J. Baker, and B. Vogelstein. 1990. p53 functions as a cell cycle control protein in osteosarcomas. Mol. Cell. Biol. 10: 5772-5781.

Dowdy, S.F., P.W. Hinds, K. Louie, S.I. Reed, A. Arnold, and R.A. Weinberg. 1993. Physical interaction of the retinoblastoma protein with human D cyclins. Cell 73: 499-511.

Dyson, N. and E. Harlow. 1992. Adenovirus ElA targets key regulators of cell proliferation. Cancer Surveys 12: 161-195.

Ellmeier, W., A. Aguzzi, E. Kleiner, R. Kurzbauer, and A. Weith. 1992. Mutually exclusive expression of a helix-loop-helix gene and $\mathrm{N}$-myc in human neuroblastomas and in normal development. EMBO /. 11: 2563-2571.

Ewen, M.E., H.K. Sluss, C.J. Sherr, H. Matsushime, J. Kato, and D.M. Livingston. 1993. Functional interactions of the retinoblastoma protein with mammalian D-type cyclins. Cell 73: 487-497.

Fung, Y.K., A. T'Ang, A.L. Murphree, F.H. Zhang, W.R. Qiu, S.W. Wang, X.H. Shi, L. Lee, B. Driscoll, and K.J. Wu. 1993. The $\mathrm{Rb}$ gene suppresses the growth of normal cells. Oncogene 8: 2659-2672.

Goodrich, D.W., N.P. Wang, Y.W. Qian, E.Y. Lee, and W.H. Lee. 1991. The retinoblastoma gene product regulates progression through the G1 phase of the cell cycle. Cell 67:293302.

Gu, W., J.W. Schneider, G. Condorelli, S. Kaushal, V. Mahdavi, and B. Nadal-Ginard. 1993. Interaction of myogenic factors and the retinoblastoma protein mediates muscle cell commitment and differentiation. Cell 72: 309-324.

Harlow, E. and D. Lane. 1988. Antibodies. A laboratory manual. Cold Spring Harbor Laboratory, Cold Spring Harbor, New York.

Helin, K., J.A. Lees, M. Vidal, N. Dyson, E. Harlow, and A. Fattaey. 1992. A cDNA encoding a pRB-binding protein with properties of the transcription factor E2F. Cell 70: 337-350.

Higuchi, R., B. Krummel, and R.K. Saiki. 1988. A general method of in vitro preparation and specific mutagenesis of DNA fragments: Study of protein and DNA interactions.
Nucleic Acids Res. 16: 7351-7367.

Hinds, P.W., S. Mittnacht, V. Dulic, A. Arnold, S.I. Reed, and R.A. Weinberg. 1992. Regulation of retinoblastoma protein functions by ectopic expression of human cyclins. Cell 70: 993-1006.

Hu, Q.J., N. Dyson, and E. Harlow. 1990. The regions of the retinoblastoma protein needed for binding to adenovirus E1A or SV40 large T antigen are common sites for mutations. EMBO J. 9: 1147-1155.

Huang, H.J., J.K. Yee, J.Y. Shew, P.L. Chen, R. Bookstein, T. Friedmann, E.Y. Lee, and W.H. Lee. 1988. Suppression of the neoplastic phenotype by replacement of the RB gene in human cancer cells. Science 242: 1563-1569.

Jen, Y., H. Weintraub, and R. Benezra. 1992. Overexpression of Id protein inhibits the muscle differentiation program: In vivo association of Id with E2A proteins. Genes \& Dev. 6: 1466-1479.

Kaelin, W.G. Jr., D.C. Pallas, J.A. DeCaprio, F.J. Kaye, and D.M. Livingston. 1991. Identification of cellular proteins that can interact specifically with the T/E1A-binding region of the retinoblastoma gene product. Cell 64: 521-532.

Kaelin, W.G. Jr., W. Krek, W.R. Sellers, J.A. DeCaprio, F. Ajchenbaum, C.S. Fuchs, T. Chittenden, Y. Li, P.J. Farnham, and M.A. Blanar. 1992. Expression cloning of a cDNA encoding a retinoblastoma-binding protein with E2F-like properties. Cell 70: 351-364.

Kato, J., H. Matsushime, S.W. Hiebert, M.E. Ewen and C.J. Sherr. 1993. Direct binding of cyclin D to the retinoblastoma gene product $(\mathrm{pRb})$ and $\mathrm{pRb}$ phosphorylation by the cyclin D-dependent kinase CDK4. Genes \& Dev. 7: 331-342.

Kawaguchi, N., H.F. DeLuca, and M. Noda. 1992. Id gene expression and its suppression by 1,25-dihydroxyvitamin D3 in rat osteoblastic osteosarcoma cells. Proc. Natl. Acad. Sci. 89: 4569-4572.

Kaye, F.J., R.A. Kratzke, J.L. Gerster, and J.M. Horowitz. 1990. A single amino acid substitution results in a retinoblastoma protein defective in phosphorylation and oncoprotein binding. Proc. Natl. Acad. Sci. 87: 6922-6926.

Kreider, B.L., R. Benezra, G. Rovera, and T. Kadesch. 1992. Inhibition of myeloid differentiation by the helix-loop-helix protein Id. Science 255: 1700-1702.

Kratzke, R.A., G.A. Otterson, A.Y. Lin, E. Shimizu, N. Alexandrova, M. Zajac-Kaye, J.M. Horowitz, and F.J. Kaye. 1992. Functional analysis at the Cys706 residue of the retinoblastoma protein. J. Biol. Chem. 267: 25998-26003.

Lassar, A.B., J.N. Buskin, D. Lockshon, R.L. Davis, S. Apone, S.D. Hauschka, and H. Weintraub. 1989. MyoD is a sequence-specific DNA-binding protein requiring a region of myc homology to bind to the muscle creatine kinase enhancer. Cell 58: 823-831.

Lee, W.H., R. Bookstein, F. Hong, L.J. Young, J.Y. Shew, and E.Y. Lee. 1987a. Human retinoblastoma susceptibility gene: Cloning, identification, and sequence. Science 235: 13941399.

Lee, W.H., J.Y. Shew, F.D. Hong, T.W. Sery, L.A. Donoso, L.J. Young, R. Bookstein, and E.Y. Lee. 1987b. The retinoblastoma susceptibility gene encodes a nuclear phosphoprotein associated with DNA binding activity. Nature 329: 642-645.

Lees, J.A., K.J. Buchkovich, D.R. Marshak, C.W. Anderson, and E. Harlow. 1991. The retinoblastoma protein is phosphorylated on multiple sites by human cdc2. EMBO J. 10: 42794290.

Li, L. and E.N. Olson. 1992. Regulation of muscle cell growth and differentiation by the MyoD family of helix-loop-helix proteins. Adv. Cancer Res. 58: 95-119.

Maheswaran S., S. Park, A. Bernard, J.F. Morris, F.J. Rauscher, 
D.E. Hill, and D.A. Haber. 1993. Physical and functional interaction between WT1 and p53 proteins. Proc. Natl. Acad. Sci. 90: 5100-5104.

Maheswaran S., H. Lee, and G.E. Sonenshein. 1994. Intracellular association of the protein product of the c-myc oncogene with the TATA-binding protein. Mol. Cell. Biol. 14: 11471152.

Munger, K., B.A. Werness, N. Dyson, W.C. Phelps, E. Harlow, and P.M. Howley. 1989. Complex formation of human papillomavirus E7 proteins with the retinoblastoma tumor suppressor gene product. EMBO /. 8: 4099-4105.

Murray, S.S., C.A. Glackin, K.A. Winters, D. Gazit, A.J. Kahn, and E.J. Murray. 1992. Expression of helix-loop-helix regulatory genes during differentiation of mouse osteoblastic cells. I. Bone Min. Res. 7: 1131-1138.

Murre, C., P.S. McCaw, and D. Baltimore. 1989a. A new DNA binding and dimerization motif in immunoglobulin enhancer binding, daughterless, $\mathrm{MyoD}$, and myc proteins. Cell 56: 777-783.

Murre, C., P.S. McCaw, H. Vaessin, M. Caudy, L.Y. Jan, Y.N. Jan, C.V. Cabrera, J.N. Buskin, S.D. Hauschka, and A.B. Lassar. $1989 \mathrm{~b}$. Interactions between heterologous helix-loop-helix proteins generate complexes that bind specifically to a common DNA sequence. Cell 58: 537-544.

Ogata, T., J.M. Wozney, R. Benezra, and M. Noda. 1993. Bone morphogenetic protein-2 transiently enhances expression of a gene, Id (Inhibitor of Differentiation), encoding a helixloop-helix molecule in osteoblast-like cells. Proc. Natl. Acad. Sci. 90: 9219-9222.

Pardee, A.B. 1989. Gl events and regulation of cell proliferation. Science 246: 603-608.

Pesce, S. and R. Benezra. 1993. The loop region of the helixloop-helix protein Idl is critical for its dominant negative activity. Mol. Cell. Biol. 13: 7874-7880.

Qin, X.Q., T. Chittenden, D.M. Livingston, and W.G. Kaelin Jr. 1992. Identification of a growth suppression domain within the retinoblastoma gene product. Genes \& Dev. 6: 953-964.

Robbins, S.L. 1989. Pathologic basis of disease, 4th ed. (ed. Ramzi S. Cotran, Vinay Kumar, and Stanley L. Robbins). Saunders, Philadelphia, PA.

Rustgi, A.K., N. Dyson, and R. Bernards 1991. Amino-terminal domains of $\mathrm{c}-\mathrm{myc}$ and $\mathrm{N}$-myc proteins mediate binding to the retinoblastoma gene product. Nature 352: 541-544.

Shew, I.Y., B.T. Lin, P.L. Chen, B.Y. Tseng, T.L. Yang-Feng, and W.H. Lee. 1990. C-terminal truncation of the retinoblastoma gene product leads to functional inactivation. Proc. Natl. Acad. Sci. 87: 6-10.

Sorrentino, V., R. Pepperkok, R.L. Davis, W. Ansorge, and L. Philipson. 1990. Cell proliferation inhibited by MyoDl independently of myogenic differentiation. Nature 345: 813815.

Sun, X.H., N.G. Copeland, N.A. Jenkins, and D. Baltimore. 1991. Id proteins Id 1 and Id2 selectively inhibit DNA binding by one class of helix-loop-helix proteins. Mol. Cell. Biol. 11: 5603-5611.

Tapscott, S.J., R.L. Davis, M.J. Thayer, P.F. Cheng, H. Weintraub, and A.B. Lassar. 1988. MyoD1: A nuclear phosphoprotein requiring a Myc homology region to convert fibroblasts to myoblasts. Science 242: 405-411.

Voronova, A. and D. Baltimore. 1990. Mutations that disrupt DNA binding and dimer formation in the E47 helix-loophelix protein map to distinct domains. Proc. Natl. Acad. Sci. 87: 4722-4726.

Weinberg, R. 1991. Tumor suppressor genes. Science 254: 11381146.

Welch, P.J. and J.Y.J. Wang. 1993. A C-terminal protein-binding domain in the retinoblastoma protein regulates nuclear c-Abl tyrosine kinase in the cell cycle. Cell 75: 779-790.

Whyte, P., K.J. Buchkovich, J.M. Horowitz, S.H. Friend, M. Raybuck, R.A. Weinberg, and E. Harlow. 1988. Association between an oncogene and an anti-oncogene: The adenovirus ElA proteins bind to the retinoblastoma gene product. $\mathrm{Na}$ ture 334: 124-129.

Wilson, R.B., M. Kiledjian, C.P. Shen, R. Benezra, P. Zwollo, S.M. Dymecki, S.V. Desiderio, and T. Kadesch. 1991. Repression of immunoglobulin enhancers by the helix-loop-helix protein Id: Implications for B-lymphoid-cell development. Mol. Cell. Biol. 11: 6185-6191.

Zentella, A. and J. Massague. 1992. Transforming growth factor beta induces myoblast differentiation in the presence of mitogens. Proc. Natl. Acad. Sci. 89: 5176-5180.

Zhu, L., S. van den Heuvel, K. Helin, A. Fattaey, M. Ewen, D. Livingston, N. Dyson, and E. Harlow. 1993. Inhibition of cell proliferation by p107, a relative of the retinoblastoma protein. Genes \& Dev. 7: 1111-1125. 


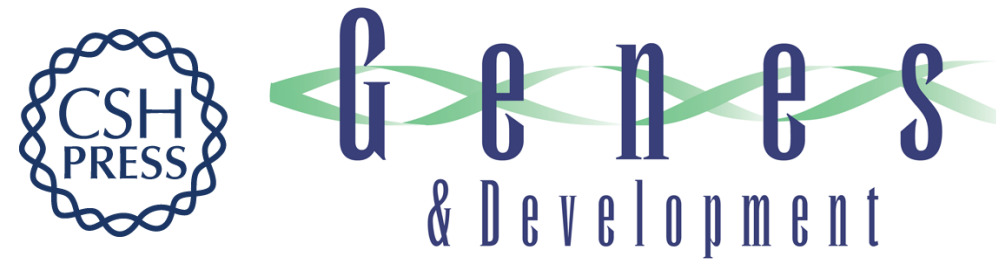

\section{The helix-loop-helix protein Id-2 enhances cell proliferation and binds to the retinoblastoma protein.}

A lavarone, P Garg, A Lasorella, et al.

Genes Dev. 1994, 8:

Access the most recent version at doi:10.1101/gad.8.11.1270

References This article cites 62 articles, 28 of which can be accessed free at:

http://genesdev.cshlp.org/content/8/11/1270.full.html\#ref-list-1

License

Email Alerting

Service

Receive free email alerts when new articles cite this article - sign up in the box at the top right corner of the article or click here.

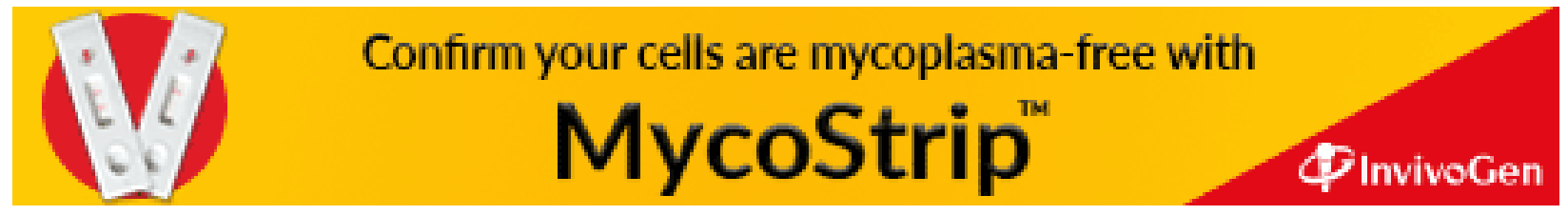

